Article

\title{
Evaluation of Co-Existence Options of Marine Renewable Energy Projects in Japan
}

\author{
A.H.T. Shyam Kularathna ${ }^{1, * \mathbb{C}}$, Sayaka Suda ${ }^{2}$, Ken Takagi ${ }^{3}$ and Shigeru Tabeta ${ }^{2}$ \\ 1 Graduate Program in Sustainability Science-Global Leadership Initiative, Graduate School of Frontier \\ Sciences, The University of Tokyo, Room 334, Building of environmental studies, 5-1-5 Kashiwanoha, \\ Kashiwa, Chiba 277-8563, Japan \\ 2 Department of Environment Systems, Graduate School of Frontier Sciences, The University of Tokyo, \\ 5-1-5 Kashiwanoha, Kashiwa, Chiba 277-8563, Japan; tfs.suda.m31@gmail.com (S.S.); \\ tabeta@k.u-tokyo.ac.jp (S.T.) \\ 3 Department of Ocean Technology, Policy, and Environment, Graduate School of Frontier Sciences, \\ The University of Tokyo, 5-1-5 Kashiwanoha, Kashiwa, Chiba 277-8563, Japan; takagi@edu.k.u-tokyo.ac.jp \\ * Correspondence: shyamkularathna@gmail.com or shyamkularathna@s.k.u-tokyo.ac.jp
}

Received: 26 April 2019; Accepted: 13 May 2019; Published: 18 May 2019

\begin{abstract}
Consensus building among local stakeholders is vital for the success of the proposed initial commercial marine renewable energy (MRE) projects in Japan. Even though the literature on stakeholder acceptance highlights the importance of creating local benefits and co-creation options, very few studies and almost no empirical data have been published on the application of non-monetary benefit creation schemes in the context of MRE. Hence, the purpose of this study was to systematically evaluate the possible co-existence options available for Japan's MRE projects through data collected from interviews and questionnaire surveys in two development sites in Nagasaki and Kitakyushu in Southern Japan. To overcome the limitations of data unavailability and uncertainty, the Dempster Shafer Analytic Hierarchy Process (DS-AHP) was used for evaluating the best co-existence strategy out of five potential options. The results indicate that local fisheries prefer the oceanographic information sharing option whereas most of the other stakeholders prefer using local resources to construct and operate the power plant, creating business involvement opportunities for the local community. Analysis of stakeholders' decision behaviors suggests that perceived impacts, knowledge, and values influence the preference decision. In addition to the validation of stakeholder preference of the previously proposed co-existence options with empirical data, this study provides a robust method to further evaluate the potential options with the availability of new data.
\end{abstract}

Keywords: marine renewable energy; co-existence; co-location; Dempster Shafer Analytic Hierarchy Process; multi-criteria analysis

\section{Introduction}

Marine renewable energy (MRE) is often considered to be the renewable energy resources that can be extracted from nearshore and offshore areas such as waves, tidal and ocean currents, thermal and salinity gradients and, offshore wind [1-3]. The estimated potential of these MRE resources is significant in comparison to the global demands [2,4]. However, most of the MRE technologies are still in the readiness phase, except for the offshore wind energy sector in some European regions [5]. From the experiences of onshore renewable energy developments and initial developments of MRE projects in Europe, it is identified that overcoming related technological and economic challenges is essential [5] but will not be sufficient for sustainable MRE development if project developers fail to achieve consensus among related stakeholders [6]. However, important differences exist in stakeholder 
engagement with MRE compared to onshore energy infrastructures [7]. Hence, the interactions between power projects and the local community are significantly different among onshore renewable energy projects and MRE projects. Unlike European MRE developments where different MRE technologies have been developing and testing steadily since the early 1980s, Japan's MRE industry development had an early but very slow start from the 1970s to 1990s. Only few pilot projects were completed in the early 2000s in Japan. However, due to the changes caused by the 2011 Fukushima nuclear disaster, development of the MRE sector accelerated. Japan is aiming to initiate the first commercial offshore wind projects within the first decade of its accelerated MRE development phase. However, the required policy regulations, as well as public perceptions, are yet to be implemented and understood for MRE developers to ensure the success of the planned commercial projects.

\subsection{Problem Definition}

Existing regulations are unclear and scattered among many agencies and no clear marine spatial planning approach is used in Japan. Nearshore areas are generally allocated to fishery industry and given to regional fishery unions with fishing rights. Offshore areas are being used on a shared permission basis. Regulations on using marine areas for MRE projects have been recently introduced [8]. The regulations and guidelines applicable to considered marine areas differs significantly according to the nature of the regulating agency. The general guideline states that MRE project developers have to achieve consensus of relevant stakeholders prior to submission of the project development proposal to obtain permission to use marine areas (exclusive use of the marine area for 30 years) for their projects [9].

Local project impacts and local benefits are one of the basic criteria being considered in the process of local acceptance decision making [10]. Reducing the risk of negative environmental impact has been identified and discussed frequently during the consensus building process. However, a little work has been completed on potential co-existence strategies that can be used to create local benefits from the introduction of MRE projects, even though providing community benefits can increase levels of local support through improving individual perceptions of MRE projects [11]. Previous studies have shown that community benefits are unlikely to increase local stakeholder support when bribery perceptions are salient [12]. Further institutionalizing community benefit schemes has the potential to reduce bribery perceptions [13]. Empirical results from a potential offshore wind farm in the United Kingdom suggested that local stakeholder support is greater if the community benefits result from an institutionalized policy guidance in comparison to the community benefit schemes created as a voluntary act by the project developers [14]. The basic problem of creating local community benefit schemes is that it normally refers only to additional voluntary measures provided by the developers, which leads to additional costs to already expensive MRE projects. Most monetary benefit creation strategies lead to higher costs to the developer, which is directly proportional to the number of beneficiaries [15]. To be acceptable by the project developers, the proposed solutions must not follow the same path of monetary benefit schemes. Conversely, it would be ideal if the additional local benefits can be created with the help of the infrastructure developed for the MRE projects (i.e., use the co-benefits of MRE infrastructure). However, there are no previous examples in the Japanese MRE context and limited literature even from other contexts are available for project developers to evaluate such potential benefit creation and co-existence strategies. Developers have to manage a variety of stakeholder groups and are generally not equipped to balance all their requirements. Hence, it is of utmost importance to evaluate options to create local project benefits and a win-win situation among all the local stakeholders of MRE projects.

Non-monetary benefit schemes have been identified as options to create community benefits from the learnings of onshore renewable energy projects [6]. Local fishery industry is the most likely to be directly impacted by MRE project deployments [16] and project structures are usually built away from community; the related social conditions as well as potential benefit creation strategies of MRE projects tend to deviate from its onshore counterpart. The Research Institute of Ocean Economics 
(RIOE) in Japan has proposed some options to create benefits for local fisheries from offshore wind projects [17]. Almost no literature or practical examples of application of non-monetary local benefit schemes are available in the context of MRE development in coastal communities. The second aspect of this problem is the lack of knowledge and experience as local MRE sector is still in the technology readiness phase. Hence, consensus building and co-existence strategy selection process have to be completed with a significant level of uncertainty. The overarching problem focused in this study is: what is the best local benefit creation and co-existing strategy preferred by stakeholders to create a win-win situation for the introduction of commercial level MRE projects in Japan?

\subsection{Case Study Sites}

This study is based on a data set collected from two case study sites from Nagasaki and Kitakyushu in Southern Japan (Figure 1) that represents the best examples of private companies trying to initiate commercial-level MRE projects after experiencing success with government funded demonstration pilot projects. The Ministry of Environment in Japan has been conducting pilot MRE projects in Nagasaki since 2010 (and developed into Japan's first full-scale grid-connected 2 MW floating offshore wind turbine) near the Goto Islands, about $100 \mathrm{~km}$ off the main Nagasaki city [18]. Initially, the project owners received some local concern about the development of MRE devices and testing in real sea conditions due to the perceived negative environmental impacts. Given the results of the pilot projects, local stakeholder acceptance of Nagasaki MRE development has increased significantly. A non-profit organization (NPO), Nagasaki Marine Industry Cluster Promotion Association (NaMICPA), comprised of more than 50 public and private entities related to marine industries, was established in 2014 with the aim of supporting the development of marine industries including the MRE sector [19]. A proposal to build the first commercial MRE project, a $22 \mathrm{MW}$ offshore wind farm has been submitted by a private company with expected commencement in 2019 [20]. The Naru strait, which lies between two smaller islands, has been identified as a potential site for tidal energy projects and authorities are in the process of establishing a marine energy test center similar to the European Marine Energy Centre (EMEC) in Scotland [21].

Similar to the inception of Nagasaki MRE projects, government agencies have started testing the feasibility of offshore wind energy development in the Hibiki Sea area in Kitakyushu, Japan in 2012 [22]. A consortium comprised of local industries, the Hibiki Wind Energy Group [23], won the bid to build the first large-scale offshore wind farm in Kitakyushu in 2017 [20], which is planned to start in 2022.

In the case of tidal energy projects amongst the Goto Islands in the Nagasaki case study area, the approval of the local fishery association is necessary since the tidal strait was already declared as a marine area with fishing rights. However, the offshore wind project in the Nagasaki case study is planned in the general offshore area where any marine user can use the area on a shared permission basis with the approval of local authorities. In contrast, the Kitakyushu offshore project is planned in marine areas governed by port law; hence, the local port authority has the exclusive control over the development site. Despite the differences in the required legal requirements, both Nagasaki and Kitakyushu MRE developers are compelled to search for means to improve public acceptance of their proposed commercial MRE projects. 


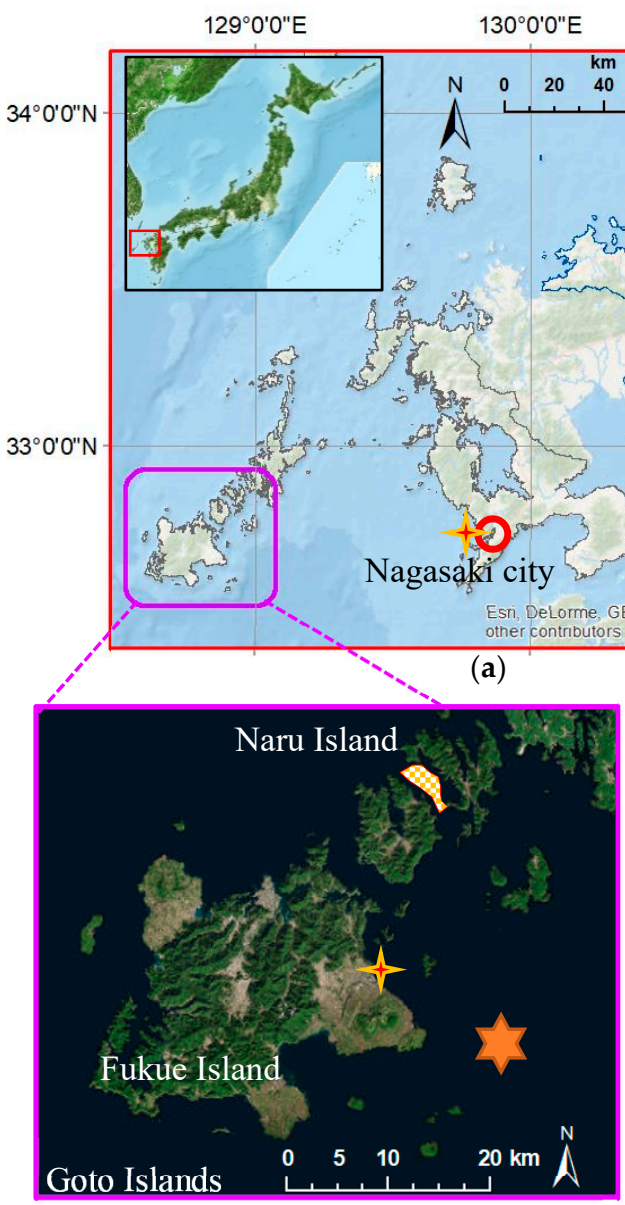

(b) $131^{\circ} 0^{\prime} 0 " \mathrm{E}$

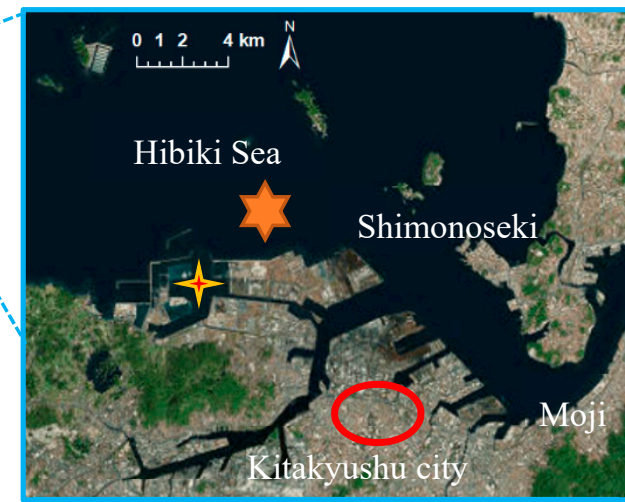

(c)

\section{Legend}

Nagasaki case study Kitakyushu case study

Shipyard and harbor

in Nagasaki city, Harbor in

Ferry terminal in Kitakyushu city

Fukue island

Port / Ferry

terminal

Closest main Nagasaki city (in the

city mainland)

Proposed

offshore wind

project area

Proposed

tidal test

project area

Ocean off the

Fukue Island

Kitakyushu city

near the harbor in

'Hibiki' sea

\begin{tabular}{|c|c|}
\hline $\begin{array}{c}\text { Naru strait (narrow } \\
\text { strait near Naru } \\
\text { Island) }\end{array}$ & n/a \\
\hline
\end{tabular}

Map Data @ 2019 ZENRIN Japan

Figure 1. Location of Nagasaki and Kitakyushu MRE development sites in Southern Japan: (a) Location of two case studies; (b) Fukue and Naru Islands (in Goto Islands) in Nagasaki case study; (c) Kitakyushu city, Moji, and Shimonoseki area in Kitakyushu case study.

\section{Materials and Methods}

\subsection{Data Collection}

The main data were collected using key stakeholder interviews and a questionnaire survey in the main communities near the Nagasaki and Kitakyushu MRE project sites. We conducted 20 key stakeholder interviews with the local fishery union representatives (7), project developers (3), local government agency respondents (3), NaMICPA non-profit organization representatives (4), and environmental observation teams including related researchers (3). Key stakeholder interviews were conducted in a semi-structured format focusing on the potential benefit creation options found in the literature.

The questionnaire survey was conducted in coastal communities of Fukue Island, Naru Island, and Nagasaki city area, representing the Nagasaki case study, whereas the Kitakyushu city area, Moji, and the Shimonoseki area represented the Kitakyushu case study. A total of 77 responses were selected as complete and valid for further analysis (Table 1). The questionnaire survey included questions to elucidate the demographic information of the respondents, potential co-existence options and evaluation criteria, pair-wise comparison of evaluation criteria, and preference of identified co-existence strategy based on each criteria. 
Table 1. Summary of valid questionnaire survey respondents.

\begin{tabular}{cccc}
\hline Stakeholder Group & \multicolumn{3}{c}{ Number of Respondents } \\
\cline { 2 - 4 } & Total & Nagasaki & Kitakyushu \\
\hline Local fishery $^{1}$ & 15 & 9 & 6 \\
Developers/Construction sector & 7 & 6 & 1 \\
Civil servants & 14 & 14 & - \\
Tourism and shipping industry & 2 & 1 & 1 \\
Health and welfare & 4 & 3 & 1 \\
Non-profit organizations (NPO), Service sector and others & 19 & 14 & 5 \\
Not indicated & 16 & 13 & 3 \\
\hline
\end{tabular}

${ }^{1}$ Fishery union officials and general fishers in the area.

\subsection{Data Analysis}

Overarching data for MRE co-existence option evaluation was analyzed using the Dempster Shafer Analytic Hierarchy Process (DS-AHP) multi-criteria decision making model. The entire process can be summarized into three main steps: (1) identification of potential co-existence options, (2) multi-criteria analysis (MCA) of identified co-existence options and, (3) evaluation of the stakeholder preferences using the DS-AHP model based on the MCA results.

\subsubsection{DS-AHP Multi-Criteria Decision Making Model}

The main data analysis method involves two fundamental decision making techniques: Analytic Hierarchy Process (AHP) and Dempster Shafer Theory (DST). AHP [24,25] is one of the most widely used multi-criteria decision making approaches in many disciplines. The main limitation of AHP is its requirement for pair-wise comparison for each option pair combination, which makes the process impractical when many options must be considered and there is a significant level of data unavailability or uncertainty. DST, which is based on the belief function, is used to overcome the limitation of handling uncertainty in the standard AHP method. DST originated from the methods developed by Dempster to estimate upper and lower probabilities [26,27] and improvements were added by Shafer [28]. DST is widely applied in the field of machine learning and artificial intelligence. The combination of AHP and DST as a multi-criteria decision making model is also known as the Dempster Shafer Analytical Hierarchy Process (DS-AHP). DS-AHP is a more robust framework suitable for decision making under uncertainty where AHP is used for rating decision criteria and DST is used for evaluation of decision options using the weighted criteria [29-31]. Only the basics of DS-AHP are explained here. Please refer the original literature [29-31] for more information.

\subsubsection{Interpretation of DS-AHP Calculation}

Let $\Theta=\left\{h_{1}, h_{2} \ldots h_{n}\right\}$ be a collectively exhaustive and mutually exclusive finite set of $n$ hypotheses or propositions, which is also called the frame of discernment. The basic probability assignment (bpa), is a function $m: 2^{\Theta} \rightarrow[0,1]$ that also satisfies the requirement $m(\phi)=0$ and $\sum_{A \subseteq \Theta} m(A)=1$, where $\phi$ represents the empty set and $2^{\Theta}$ represents the power set of $\Theta$. The assigned probability of any sub set $y$ of frame of discernment $\Theta$, (i.e., $y \subseteq \Theta$ ) is denoted by $m(y)$. $m(y)$ represents the exact belief in the proposition depicted by $y$. The assigned probability for the frame of discernment $\Theta$ (i.e., $m(\Theta)$ ), represents the global ignorance within the bpa [30].

In the DS-AHP model, $m_{i}(y)$, i.e., the bpa value for decision alternative(s) $y$ with respect to the decision criteria $i$, is calculated using Equation (1):

$$
m_{i}(y)=\frac{a_{y} W_{i}}{\sum_{j=1}^{d} a_{j} W_{i}+\sqrt{d}} \quad \text { and } \quad m_{i}(\Theta)=\frac{\sqrt{d}}{\sum_{j=1}^{d} a_{i} W_{i}+\sqrt{d}}
$$


where $a_{y}$ denotes the user preference value (1-7 preference scale from lowest preference 1 to highest preference 7), $W_{i}$ represents the weight assigned to the considered decision criteria by pair-wise comparison using the standard AHP method [25] and $d$ represents the number of decision alternatives judged by the decision maker [31].

Basic probability assignments are considered as evidence and can be combined using Dempster's rule of combination, provided that information sources are independent. Criteria-wise preference probabilities can be combined and decision maker-wise preferences can be calculated using Dempster's rule of combination in Equation (2):

$$
m_{i \oplus j}(y)= \begin{cases}0 & ; y=\phi \\ \frac{\sum_{A_{p} \cap A_{q}=y} m_{i}\left(A_{p}\right) m_{j}\left(A_{q}\right)}{1-\sum_{A_{p} \cap A_{q}=\phi} m_{i}\left(A_{p}\right) m_{j}\left(A_{q}\right)} & ; y \neq \phi\end{cases}
$$

where $m_{i \oplus j}(y)$ denotes the combined preference probability with respect to decision criteria $i$ and $j$. This combination rule is used again to aggregate the individual decision maker's preference levels to derive the group preference, taking each decision maker as a criteria [31].

Belief level, denoted by $\operatorname{Bel}(y)$ represents the confidence or exact support for the proposition $y$ or the confidence level that hypothesis $y$ is true. Plausibility level, denoted by $P l s(y)$, represents the possibility of support for proposition $y$ or the maximum amount of confidence that could be placed on $y$. Both belief and plausibility are functions: $2^{\Theta} \rightarrow[0,1]$ and constitute the interval of support for the considered proposition $y$. The two functions are related to each other by $\operatorname{Pls}(y)=1-\operatorname{Bel}(\bar{y})$ where $\bar{y}$ represents the complement of $y$. The interval between belief and plausibility levels represents the uncertainty level because $[\operatorname{Bel}(y), P l s(y)]$ represents the lower and upper bounds of the probability by which the considered proposition $y$ is supported $[28,32]$. The final belief level and the plausibility levels are calculated by Equation (3).

$$
\operatorname{Bel}(S)=\sum_{B \subseteq S} m(B) \forall S \subseteq \Theta \quad \text { and } \quad P l s(S)=\sum_{B \cap S \neq \varnothing} m(B) \forall S \subseteq \Theta
$$

\subsection{Option Identification and DS-AHP Decision Hierarchy}

The potential co-existence options were basically identified by analyzing the proposal made by the Research Institute of Ocean Economics in Japan [17], and systematically understanding the real project stakeholders' perceptions of each proposal via key stakeholder interviews and other related literature. After identifying the potential and the applicability, the proposed co-existence options were categorized into five main options: (O1) sharing in-situ, real time oceanographic information; (O2) using MRE structures as artificial reefs and support structures for commercial fishing; (O3) co-location with other industries such as leisure and tourism, aquaculture, etc.; $(\mathrm{O} 4)$ sharing generated electricity for local users at a subsidized rate; and (O5) use of local resources to construct and operate the power plant, creating business involvement opportunities. Table 2 provides a summary of the option identification. In the next step, local relevance, expected impacts, and limitations of each identified option were analyzed with the data from key stakeholder interviews.

From the key stakeholder interviews, we identified that most of the considered co-existence options have not been used similarly, even in other contexts. Hence, the potential interactions and impacts were still unknown, making direct quantitative evaluation unreliable. Instead, the preference was evaluated based on perceived potential impacts identified during key stakeholder interviews. A broader set of criteria, i.e., economic impacts, environmental impacts, and stakeholder engagement and other social impacts, was selected as the preference decision criteria in the decision hierarchy shown in Figure 2a. The individual stakeholder-wise decisions to aggregate to a group decision were combined using the equally weighted decision makers approach, where individual decision makers of the considered group are considered as equally weighted decision criteria according to the DS-AHP group decision methodology [31] (Figure 2b). 
Table 2. Summary of co-existence strategy identification.

\begin{tabular}{|c|c|c|}
\hline $\begin{array}{l}\text { Selected Co-Existence } \\
\text { Options }\end{array}$ & $\begin{array}{l}\text { Options Proposed by } \\
\text { Research Institute of Ocean } \\
\text { Economics (RIOE), Japan [17] }\end{array}$ & Key Findings from Other Literature \\
\hline $\begin{array}{l}\text { O1. Providing real-time, } \\
\text { in-situ ocean information } \\
\text { from MRE farms }\end{array}$ & $\begin{array}{l}\text { Providing marine information } \\
\text { in real-time }\end{array}$ & $\begin{array}{l}\text { Japanese marine users receive ocean } \\
\text { information from satellite observations, } \\
\text { buoys, and other user specific monitoring } \\
\text { platforms [17,33]. Stakeholders have different } \\
\text { oceanographic information demands [34]. } \\
\text { Direct economic valuation and cost benefit } \\
\text { analysis of ocean information is } \\
\text { impractical [35]. Marine energy is mostly } \\
\text { harvested in murky and high energetic places } \\
\text { where conventional data acquisition } \\
\text { techniques are impractical [36]. }\end{array}$ \\
\hline \multirow{2}{*}{$\begin{array}{l}\text { O2. Using MRE structures } \\
\text { as artificial reefs and } \\
\text { support structures for } \\
\text { commercial fishing }\end{array}$} & $\begin{array}{l}\text { Use MRE structures as artificial } \\
\text { reefs for Nurseries/Fishing }\end{array}$ & $\begin{array}{l}\text { Constraints, opportunities, and perceptions of } \\
\text { co-locating offshore wind farms and } \\
\text { fisheries }[37,38] \text {, mitigation agenda for fishing } \\
\text { effort displacement [39]. }\end{array}$ \\
\hline & $\begin{array}{l}\text { Using MRE structures to } \\
\text { support fishery gears }\end{array}$ & $\begin{array}{l}\text { Potential for co-location of passive gear } \\
\text { fisheries with offshore wind [40]. Potential for } \\
\text { and limitations of co-locating fisheries inside } \\
\text { offshore wind farms [41]. }\end{array}$ \\
\hline \multirow{2}{*}{$\begin{array}{l}\text { O3. Co-location with other } \\
\text { industries such as leisure, } \\
\text { tourism, and aquaculture }\end{array}$} & $\begin{array}{l}\text { Co-location with aquaculture } \\
\text { facilities (e.g., Fish, Oyster, } \\
\text { and Algae) }\end{array}$ & $\begin{array}{l}\text { Co-locating offshore wind farms and } \\
\text { aquaculture facilities }[38,42-45] \text {. Device } \\
\text { placement has many other technical } \\
\text { requirements [46] }\end{array}$ \\
\hline & $\begin{array}{l}\text { Co-location with leisure } \\
\text { facilities (e.g., diving, } \\
\text { recreational fishing etc.) }\end{array}$ & $\begin{array}{l}\text { Potential for limited entry recreational fishery } \\
\text { in wind farms [47], snorkeling, tourism [48], } \\
\text { angling, and yachting }[43,49]\end{array}$ \\
\hline $\begin{array}{l}\text { O4. Sharing generated } \\
\text { electricity for local users at } \\
\text { a subsidized rate }\end{array}$ & $\begin{array}{l}\text { Use of electricity generated to } \\
\text { power fishery port facilities } \\
\text { and electric boats }\end{array}$ & $\begin{array}{l}\text { Proposal for using wind energy to power } \\
\text { fishery ports [50], harbors [51], desalination } \\
\text { plants [52]. }\end{array}$ \\
\hline \multirow{2}{*}{$\begin{array}{l}\text { O5. Use of local resources } \\
\text { to construct and operate } \\
\text { the power plant creating } \\
\text { business involvement } \\
\text { opportunities }\end{array}$} & $\begin{array}{l}\text { Project participation by using } \\
\text { fishery boats for construction } \\
\text { and maintenance of the } \\
\text { power plant }\end{array}$ & $\begin{array}{l}\text { Use of fishing vessels for offshore energy } \\
\text { projects [53]. Availability of crew and vessels } \\
\text { is an important factor influencing the } \\
\text { planning and cost of maintenance of MRE. } \\
\text { Laws and regulations also influence MRE } \\
\text { operation and maintenance (O\&M) [54,55]. }\end{array}$ \\
\hline & $\begin{array}{l}\text { Project participation by } \\
\text { providing investment } \\
\text { opportunities in MRE business }\end{array}$ & $\begin{array}{l}\text { Creating business investment opportunities } \\
\text { as an acceptance improvement measure [56]. } \\
\text { Local ownership or financial participation } \\
\text { contribute to the acceptance of MRE } \\
\text { projects [57]. }\end{array}$ \\
\hline
\end{tabular}




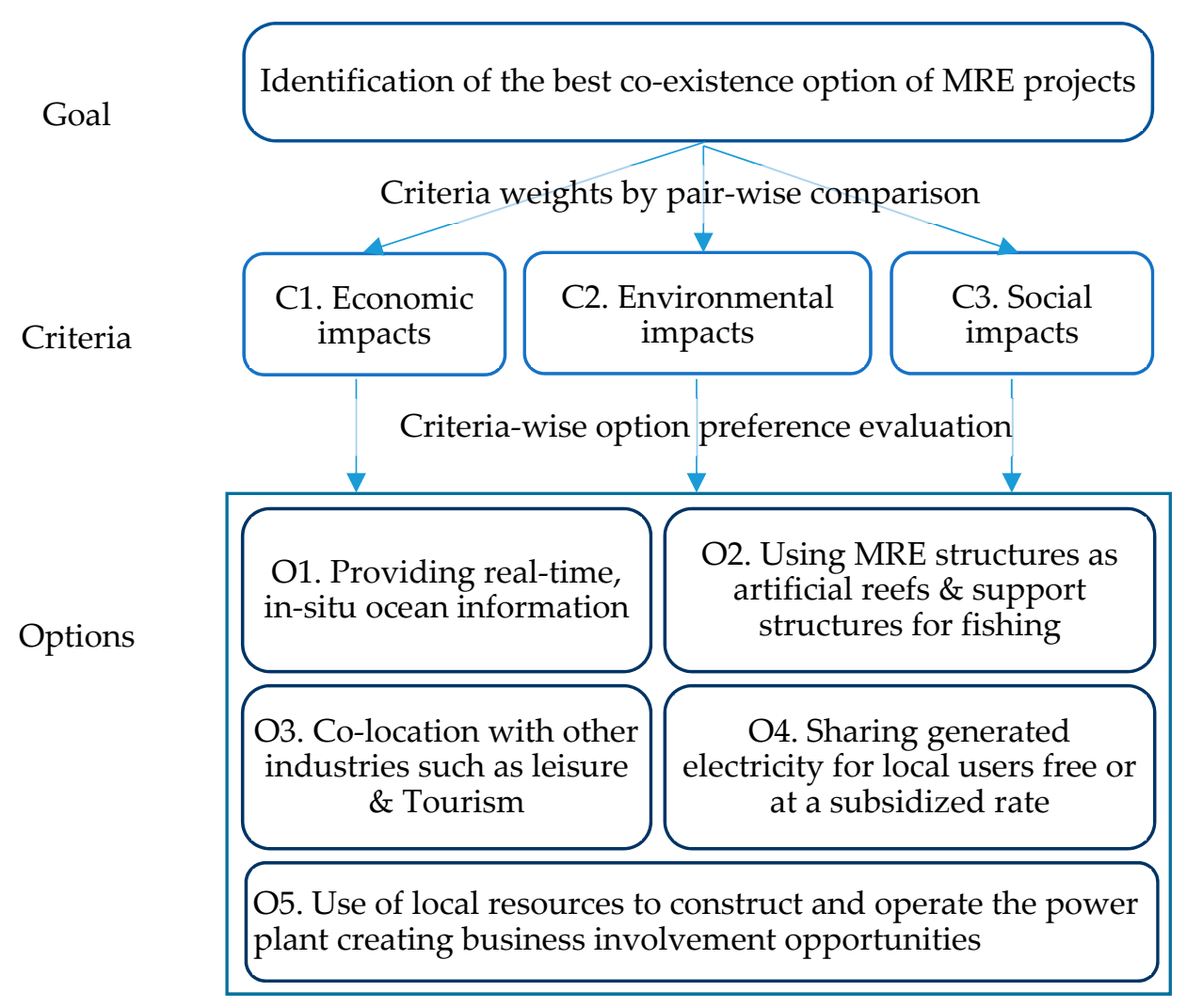

(a)

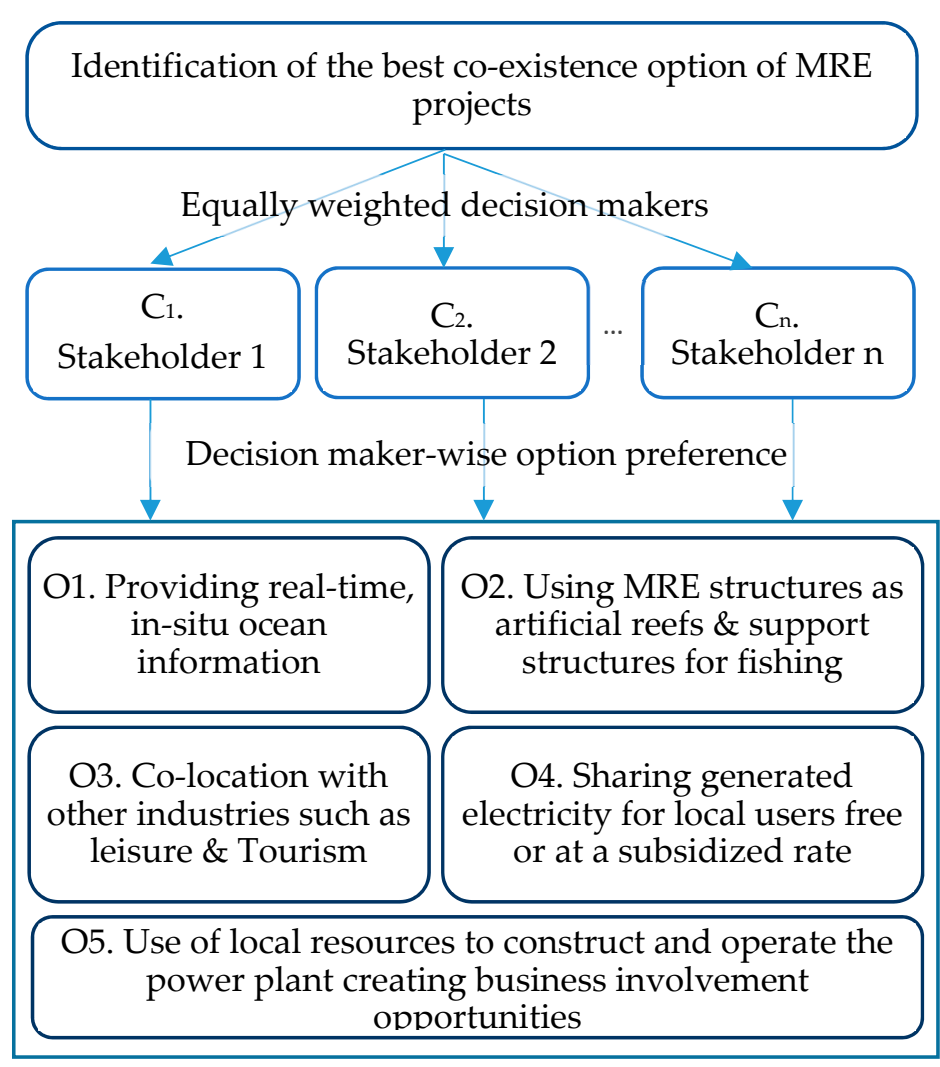

(b)

Figure 2. Dempster Shafer Analytical Hierarchy Process (DS-AHP) decision hierarchy: (a) stakeholder-wise decision and (b) group decision [31]. 


\section{Results}

As the last part of option identification, non-monetary co-existence options identified from literature were confirmed via stakeholder interviews. Stakeholder interviews were conducted in a semi-structured format that focused on the expected potential impacts, related costs and benefits, and the related risks and limitations of the proposed co-existence options. Table 3 summarizes the main points provided by the key stakeholders during the interviews.

Table 3. Summary of stakeholder interviews on expected impacts, related costs and benefits, and risks and limitations of proposed co-existence options.

\begin{tabular}{|c|c|}
\hline Co-Existence Option & Expected Impacts, Related Costs and Benefits, Risks and Limitations \\
\hline $\begin{array}{l}\text { O1. Providing real-time, in-situ ocean } \\
\text { information from MRE farms }\end{array}$ & $\begin{array}{l}\text { Real-time in-situ ocean information is valuable to the marine users } \\
\text { due to travel cost reductions, risk reductions, and improvements in } \\
\text { commercial marine industries such as fisheries (by efficient fishing } \\
\text { ground selection, stock estimations, etc.) and navigation } \\
\text { (improvements in safety, route planning, etc.) } \\
\text { Can be identified as a co-benefit of the MRE projects since most } \\
\text { commonly-required ocean information can be generated from the } \\
\text { Condition Monitoring System (CMS) of the power farm. } \\
\text { - Stakeholder engagement can be improved since many stakeholders } \\
\text { directly or indirectly use ocean information. } \\
\text { The additional cost to developers is insignificant (if there is no ocean } \\
\text { monitoring equipment to be installed in addition to the power plant's } \\
\text { standard CMS) and not proportional to the number of beneficiaries } \\
\text { due to the existence of cheap information dissemination methods. } \\
\text { Equality and scalability can be improved if the governance of } \\
\text { information sharing is well-maintained. } \\
\text { There is a risk of stakeholder conflicts due to the exposure of marine } \\
\text { information that is considered trade secret (such as fishing grounds). } \\
\text { Information about the marine environment can lead to better } \\
\text { eco-system management as well as unsustainable exploitation of } \\
\text { marine resources (such as over fishing) unless there is proper } \\
\text { governance of shared ocean information. }\end{array}$ \\
\hline
\end{tabular}

- Artificial reef effect and resulting positive spillover effect to the surrounding fishing grounds can be considered a co-benefit of MRE projects.

- Use of sub-structures to support fisheries can be a benefit if there is no significant additional cost to the developer and fishing gear does not adversely interact with the MRE devices.

- Only certain types of fishers can benefit since many fishing methods are being used in the case study areas.

O2. Using MRE structures as artificial reefs and support structures for fishing
- Scalability is directly dependent of the size of the MRE farm.

- There is a high possibility of increasing the initial construction costs as well as O\&M costs if MRE structures are used as support structures for fishing operations. Impact to the overall Levelized Cost of Energy (LCOE) and the net benefits to the fishery industry should be considered when conducting a detailed cost-benefit analysis for this option.

- Artificial reef effects caused by bio-fouling as well as fishing operations near MRE devices can pose significant operational risks and unforeseen problems. 
Table 3. Cont.

\begin{tabular}{ll}
\hline \multicolumn{1}{c}{ Co-Existence Option } & Expected Impacts, Related Costs and Benefits, Risks and Limitations \\
\hline - $\quad \begin{array}{l}\text { Aquaculture is one of the best co-location options; however, it } \\
\text { depends on how fishing gears can be used with MRE structures. } \\
\text { With the combination of reef effects and remote monitoring facilities } \\
\text { (e.g., detection of fish within MRE farms [36]), aquaculture facilities } \\
\text { combined with MRE farms seems to be an attractive solution. }\end{array}$ \\
- $\begin{array}{l}\text { Local tourism can be improved by having visible MRE projects } \\
\text { as well as organizing boat excursions to the power farm areas. Reef } \\
\text { effect creates an environment conducive for snorkeling and diving. }\end{array}$ \\
$\begin{array}{l}\text { O3. Co-location with other industries } \\
\text { such as leisure, tourism, and } \\
\text { aquaculture }\end{array}$ \\
$\begin{array}{l}\text { There should be a practical method of regulating the interactions to } \\
\text { maintain the safety and efficiency of both industries. }\end{array}$ \\
$\begin{array}{l}\text { Due to the nature of operations, such as travel planning, aquaculture } \\
\text { facilities (specially seaweeds culture) and leisure facilities have the } \\
\text { same characteristics that differ from typical large-scale fishing. } \\
\text { Operations performed in marine environments near MRE farms can } \\
\text { pose significant risks to the MRE devices as well as the } \\
\text { involved personnel. } \\
\text { LCOE can be impacted by additional construction or O\&M costs due } \\
\text { to co-location attempts. }\end{array}$
\end{tabular}

O4. Sharing generated electricity for local users at a subsidized rate
- Local fishery harbors and fish processing plants can be the best candidates for receiving subsidized electricity.

- Under current regulations, it is illegal for the utility company to differentiate the electricity rates based on other factors. Hence, limiting the number of beneficiaries is difficult unless clear policy-level guidance is introduced.

- Additional costs are directly proportional to the number of beneficiaries, thus limiting scalability and economic viability.

- $\quad$ Offshore charging points for electric boats (like charging stations for electric vehicles on land) can be created in the future; however, those technologies are too uncertain and impractical given existing costs.

- LCOE can be impacted by additional construction or O\&M costs due to potential additional requirements of local electricity grid management.
O5. Use of local resources to construct and operate the power plant creating business involvement opportunities
- $\quad$ Shipping vessels can be used for logistic purposes during the environmental impact assessment, construction, as well as maintenance phase of the power farm. Local fishers can be recruited for monitoring purposes in the offshore area.

- If the local fishery union can invest in the project, the sense of ownership can lead to a better performance of fishers as guards of the power farm.

- However, the local capacity within fisheries is limited and legal regulations have to be adopted accordingly.

- Local ports, the steel industry in Kitakyushu, and the ship building industry in Nagasaki can be strategic partners of future MRE projects.

- LCOE can be positively impacted by using local resources from already established sources and industries. However, LCOE can be adversely impacted if the initial MRE projects have to invest in capacity building of the local sources to make them qualified and competent enough to be involved with the MRE projects.

\subsection{Qualitative Multi-Criteria Analysis}

At the end of the interviews, stakeholders' perceptions about the proposed co-existence options were analyzed using multi-criteria analysis (MCA). Since no common unit of measurement exists 
for each criterion selected, and the stakeholders did not have a quantifiable amount for each criterion, multi-criteria evaluation was qualitatively completed based on their perceptions and reported perceived impacts.

Economic aspects were considered using three sub-criteria. The project co-benefit criterion measures the extent of the considered co-existence option being a co-benefit of the MRE project. Co-benefit was roughly contextualized as all secondary benefits of the MRE project other than the intended benefit of sustainable renewable energy supply. The second sub-criterion under economic aspects was the measure of variable cost to the developer, i.e., the amount of additional costs the developer has to incur for each additional beneficiary. The lower the variable cost, the lower the project cost. Since the sea area has vague ownership due to the lack of a well-established marine spatial plan, limiting the number of beneficiaries is practically difficult. This is the main reason for the unviability of monetary compensation schemes. The third economic sub-criterion is related to scalability of the solution without adding significant developer costs. Indirectly, it can be described as the ability to provide the same level of service without adding significant fixed costs to the developer. Impacts to marine environment and greenhouse gas (GHG) emission levels were the main ideas highlighted during the interviews regarding environmental impacts. Social implications were measured by three common social criteria: stakeholder engagement, level of incentives to the stakeholder, and equality. The level of incentives can be an indirect and qualitative measure of the perceived benefit levels. Equality is considered between all the stakeholder groups in the local context. Table 4 summarizes the qualitative MCA of the selected co-existence options. Qualitative MCA results that had no common unit of measurement were converted to three quantitative measures indicated by $\checkmark$ (affirmative/positive impacts), - (not sure), and $x$ (non-affirmative/negative impacts). The number of repetitions (up to three times) of the symbols $\checkmark$ and $x$ represents the degree of agreement (tendency to somewhat agree, agree, and strongly agree, respectively) for all the stakeholder interviews considered cumulatively. This level assignment of was completed based on the authors' best estimates and based on the characteristics of the interview results such as the frequency of mentioning the considered point and the level of confidence of the interviewee regarding the considered point.

The main limitations of the considered co-existence options identified during key stakeholder interviews are shown in the last row of Table 4. For example, the main concerns mentioned regarding the ocean information sharing option were: how the shared information will be used in the context of competitive fishing ground selection, who will be given the information because some fishery groups maintain knowledge about fishing grounds as a local trade secret and fishers from outside areas also have the possibility to use the same fishing area, and if the new information will cause sustainable stock management or over exploitation of fishery resources. All these concerns have to be handled by establishing good governance for using the shared information. Only a certain type of fishers can benefit from the second option of using MRE structures as artificial reefs or support structures for fishing gear. Hence, unequal cost-benefit distribution and limitations of scaling the benefits to other stakeholders were mentioned as limitations of the second option. Since there are no prior examples of combining aquaculture or leisure facilities with other offshore activity, there is a significant uncertainty for the feasibility of the third option, even though the possibility was recognized by the stakeholders. Local utility company representatives indicated that they are legally bound to maintain equality in terms of pricing the electricity for their customers, so the electricity rate for different customers or stakeholder groups cannot be significantly differentiated. Fishery union representatives and the developers identified the limitations of the fifth option as the requirement of specialized skills and other resources to become involved with the MRE sector. For example, even though the fishery vessels can be used as power plant monitoring resources (at a certain distance), they might not be capable of being used as a logistic means to reach or repair the MRE devices. The limitations of local capacity were identified as the main limitation of the fifth co-existence option of using local resources to construct, maintain, and operate the power plant and creating business involvement opportunities. 
Table 4. Multi-criteria analysis (MCA) of co-existence options.

\begin{tabular}{|c|c|c|c|c|c|c|}
\hline \multirow{2}{*}{\multicolumn{2}{|c|}{ Key Criteria }} & \multicolumn{5}{|c|}{ Co-Existence Option } \\
\hline & & $\begin{array}{l}\text { O1. Providing } \\
\text { Real-Time, } \\
\text { In-Situ } \\
\text { Oceanographic } \\
\text { Information } \\
\text { from MRE } \\
\text { Farms }\end{array}$ & $\begin{array}{l}\text { O2. Using } \\
\text { MRE } \\
\text { Structures as } \\
\text { Artificial } \\
\text { Reefs and as } \\
\text { Fishery } \\
\text { Support } \\
\text { Structures }\end{array}$ & $\begin{array}{c}\text { O3. Co-Location } \\
\text { with Industries } \\
\text { like Leisure, } \\
\text { Tourism, and } \\
\text { Aquaculture. }\end{array}$ & $\begin{array}{l}\text { O4. Sharing } \\
\text { Generated } \\
\text { Electricity for } \\
\text { Local Users at } \\
\text { a Subsidized } \\
\text { Rate }\end{array}$ & $\begin{array}{c}\text { O5. Use of } \\
\text { Local Resources } \\
\text { to Create } \\
\text { Business } \\
\text { Involvement } \\
\text { Opportunities }\end{array}$ \\
\hline \multirow{3}{*}{ 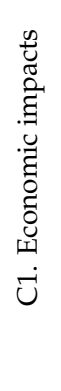 } & $\begin{array}{c}\text { Project } \\
\text { Co-benefits }\end{array}$ & $\checkmark \checkmark \checkmark$ & $\checkmark \checkmark$ & $\checkmark \checkmark \checkmark$ & $\mathrm{x}$ & $\checkmark \checkmark \checkmark$ \\
\hline & $\begin{array}{l}\text { Cost not } \\
\text { proportional } \\
\text { to the No. of } \\
\text { beneficiaries }\end{array}$ & $\checkmark \checkmark \checkmark$ & $\mathrm{x}$ & $\checkmark$ & $x x$ & $\checkmark$ \\
\hline & Scalability & $\checkmark \checkmark \checkmark$ & - & - & $x$ & $\checkmark$ \\
\hline \multirow{2}{*}{ 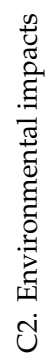 } & $\begin{array}{l}\text { Marine } \\
\text { Mnvironment }\end{array}$ & - & - & $\checkmark$ & - & $\checkmark$ \\
\hline & Emissions & $\checkmark$ & $\checkmark \checkmark$ & - & $\checkmark \checkmark$ & $\checkmark$ \\
\hline \multirow{3}{*}{ 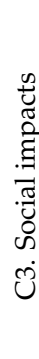 } & $\begin{array}{l}\text { Stakeholder } \\
\text { engagement }\end{array}$ & $\checkmark \checkmark$ & $\checkmark \checkmark$ & $\checkmark \checkmark$ & $\checkmark \checkmark \checkmark$ & $\checkmark \checkmark \checkmark$ \\
\hline & $\begin{array}{l}\text { Stakeholder } \\
\text { incentives }\end{array}$ & $\checkmark \checkmark$ & $\checkmark$ & $\checkmark$ & $\checkmark \checkmark \checkmark$ & $\checkmark \checkmark$ \\
\hline & Equality & $\checkmark \checkmark$ & - & $\checkmark$ & - & $\checkmark$ \\
\hline \multicolumn{2}{|c|}{ Main limitations } & $\begin{array}{l}\text { Lack of } \\
\text { information } \\
\text { sharing } \\
\text { governance }\end{array}$ & $\begin{array}{c}\text { Limited } \\
\text { scalability and } \\
\text { unequal cost } \\
\text { benefit } \\
\text { distribution }\end{array}$ & $\begin{array}{l}\text { Uncertainty on } \\
\text { economic } \\
\text { feasibility with } \\
\text { the adjustments } \\
\text { required }\end{array}$ & $\begin{array}{l}\text { Legal barriers } \\
\text { and limiting } \\
\text { number of } \\
\text { beneficiaries }\end{array}$ & $\begin{array}{l}\text { Limited local } \\
\text { capacity }\end{array}$ \\
\hline
\end{tabular}

Note: $\checkmark$ : Affirmative/positive impacts, -: not sure, $x$ : non-affirmative/negative impacts (Ratings were assigned according to the cumulative stakeholder inputs).

\subsection{Stakeholder Group-Wise Group Decision}

The next step in the co-existence option evaluation involved using the results of MCA with the DS-AHP decision making model according to the selected decision hierarchy (Figure 2) to identify the optimal solution. Figure 3 indicates the criteria weights (obtained by pair-wise comparison as in AHP method) of the selected criteria (in the left column), and the final belief and plausibility levels of support for the considered co-existence options (in the right column) for both case study 
areas. The responses were grouped considering the prominence assigned to the stakeholder group as well as the unique characteristics of their responses. Respondents representing the local fisheries assigned a higher weight to economic and environmental impacts ( $\mathrm{C} 1$ and $\mathrm{C} 2$, respectively) than the social impacts (C3) (Figure 3a). The fisheries are the main stakeholder group who frequently require oceanographic information for their daily industrial activities. Interviews with fishery unions indicated the value of subsea information for estimating fish stock, fishing ground, viable catch, and the safety of marine activities. All these factors support their preference of considering oceanographic information as the best option (Figure 3b). Even though they were interested in the fifth option, fishers also raised the question about the real potential of being involved with the MRE project developments and operation, because they have a better understanding of what is required to work in offshore conditions based on their experience. Interviews with fishers showed that fishing vessels can be used for logistic purposes during the environmental impact assessment phase and maintenance phase of the power farm. The potential of recruiting local fishers for monitoring purposes of the power plant was also mentioned. However, fishery union leaders identified that the vessels used for local fishing may not be suitable for MRE projects and the ageing fishery community may not be willing to accept new challenges related to MRE projects. However, this type of interaction with fishery and the MRE industry may attract the younger generation to the fishery industry. In addition to the above factors, the low weight assigned to the social impacts contributed to not selecting the fifth option as a preferred option. The second best alternative for fishers was the second option; however, its preference level was significantly lower than that for the first option. Fishers identified that they can benefit from the artificial reef effects, which have a spillover effect on the surrounding fishing grounds. Fishers indicated that they can reduce costs related to their fishing gear setups (such as fixed nets) if they receive structural support from the MRE structures. The value of real-time in-situ ocean information was again highlighted when the fishers discussed their fishing methods and fishing gear, such as the ability of local fishers to protect their fixed net setups, aquaculture setups, etc., in the event of a sudden ocean currents, commonly known as Kyucho in Japan [58,59]. Another advantage of in-situ ocean information is the ability of fishers to predict the ocean conditions and decide if the fishing gear is suitable before travelling to the area. Further analysis of fisheries preference is discussed in the next section due to their importance to the stakeholder group among all other stakeholders as well as their unique decision behavior.

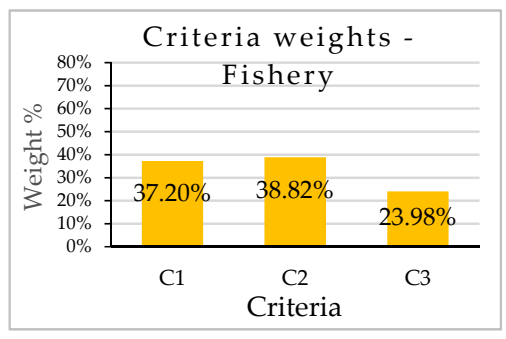

(a)

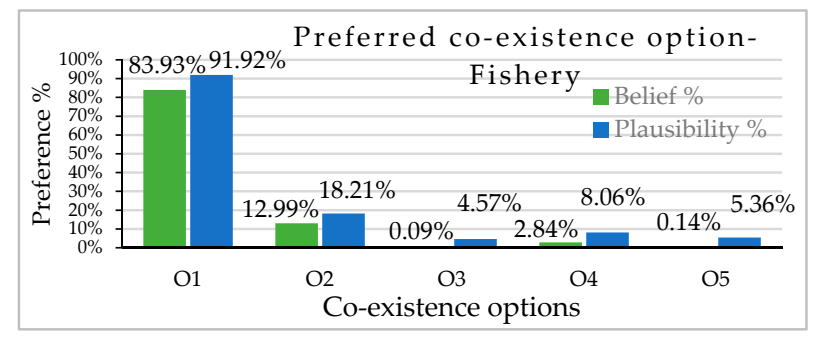

(b)

Figure 3. Cont. 


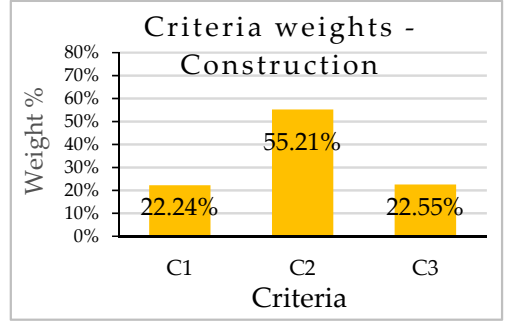

(c)

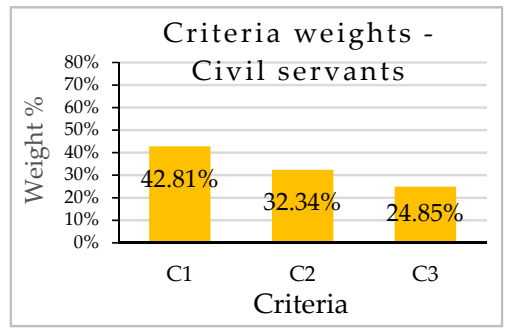

(e)

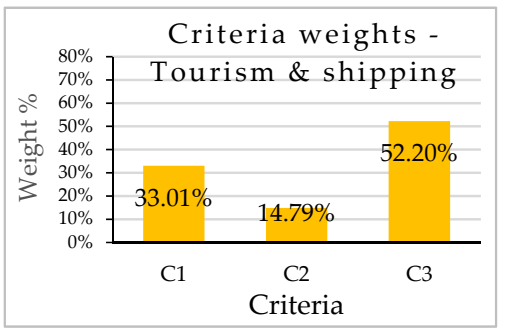

(g)

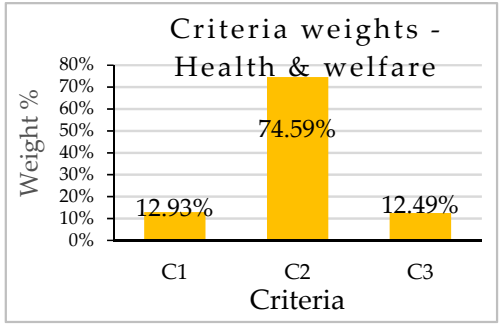

(i)

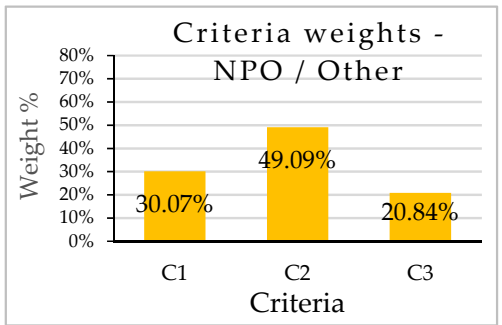

$(\mathbf{k})$

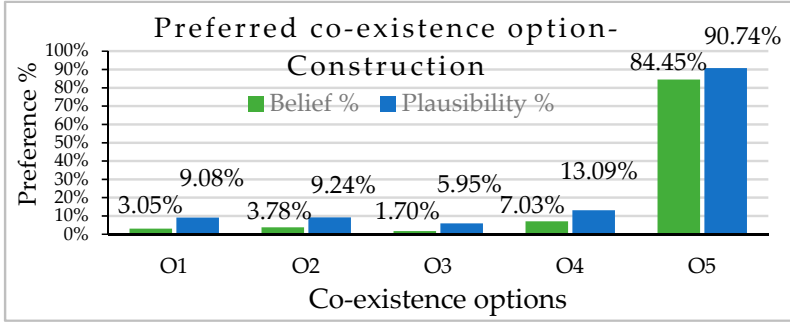

(d)

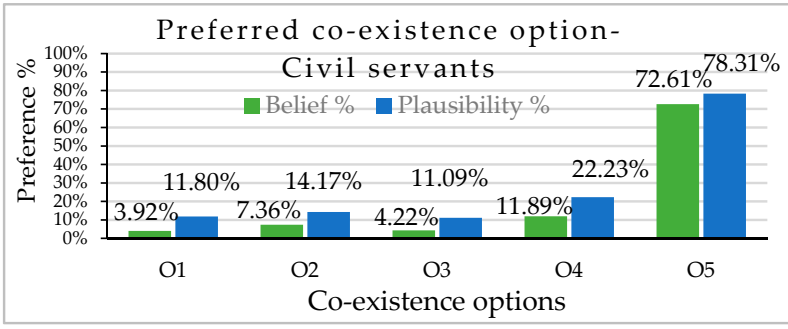

(f)

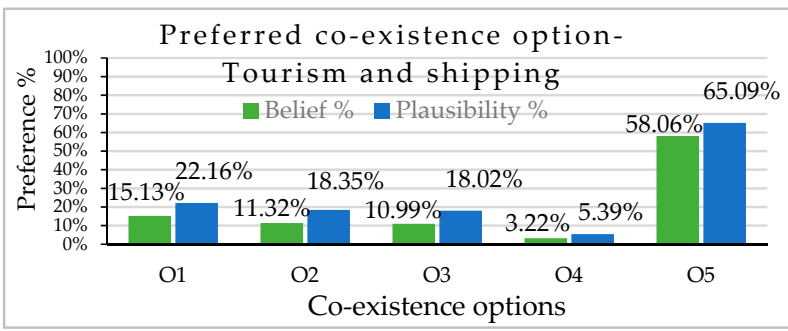

(h)

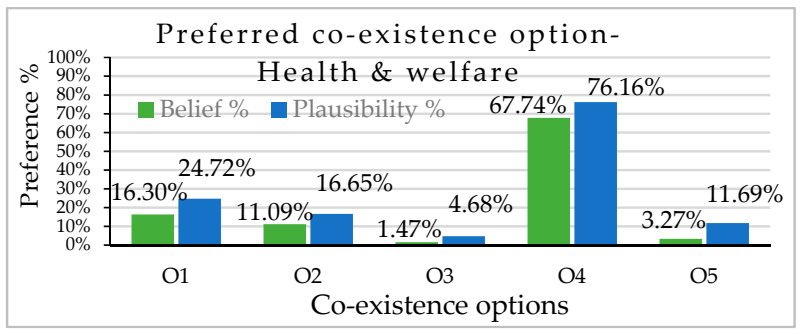

(j)

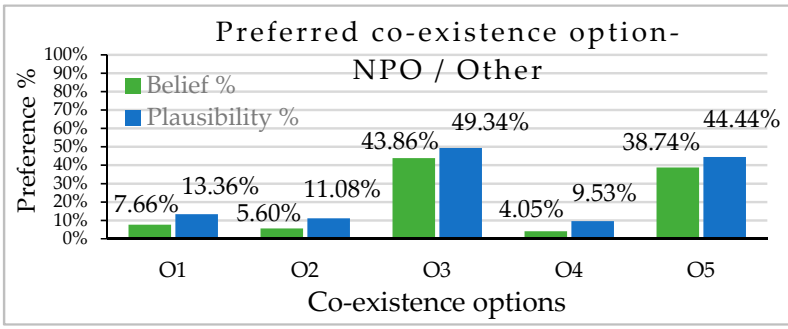

(1)

Figure 3. Stakeholder group-wise preference decision (a) average criteria weights and (b) option preference of fisheries; (c) average criteria weights and (d) option preference of construction sector respondents; (e) average criteria weights and (f) option preference of civil servants; (g) average criteria weights and (h) option preference of tourism \& shipping industry respondents; (i) average criteria weights and $(\mathbf{j})$ option preference of health and welfare sector respondents; $(\mathbf{k})$ average criteria weights and (1) option preference of NPO and other respondents. 
Figure $3 c$,d indicate the criteria weights assigned by and the final preference of the respondents from the construction industry. These respondents are expected to be involved with the MRE projects during its development phase. These results can generally represent the opinion of future MRE project developers. They assigned the highest weight to the environmental impacts. However, the environmental impacts of most of the considered co-existence options are either not known or insignificant (Table 4). The high weight assigned to environmental impacts does not represent the final preference level where the highest preference was for the fifth option. Interviews with the project developers indicated that there is a high possibility of involving local fishers through the local fishery union for the initial stages of MRE project development, such as using their fishing vessels to conduct surveys and environmental impact assessment. The fifth option is the only option that can be directly employed for project development so the developers directly benefit from it. According to the project developers, there can be long term benefits in terms of improving LCOE due to the use of local resources and developing local supply chain industries, even though additional initial investments could be required for building local capacities to meet the requirements of the MRE industry.

Figure $3 \mathrm{e}$,f indicate the criteria weights assigned by and the final preferences of the respondents from the civil service sector. They assigned the highest weight to the economic impacts criterion. They selected the fifth option as the best option among the options. Interviews conducted with local government officers and other civil servants like school teachers indicated that they have no direct involvement with the marine affairs. We separately analyzed the results from the health and welfare sector respondents due to unique characteristics that will be explained later. The group of civil servants considered in Figure 3e,f can be approximated to the inland urban communities that have a vague idea that MRE projects may result in high energy costs and the local community should be given the opportunity to improve their economy.

Respondents involved with the local tourism industry and shipping industry assigned significant weight to the social impacts criterion (Figure 3g), which is comprised of stakeholder engagement, incentives, and equality. The most preferred option was the fifth option: using local resources for MRE project development and creating business involvement opportunities (Figure $3 \mathrm{~h}$ ). The literature as well as key stakeholder interviews indicated the potential for collaborating with these sectors according to both the third and fifth options. However, local respondents had no experience with how MRE projects can collaborate with local tourism industry as indicated by the third option. The high weight assigned to the social impact aspects with the current level of perception might be the reason for their preference for the fifth option over the third option.

The respondents from health and welfare sector had a unique perception of MRE options, even though they can be considered as civil servants in general. This group had in-depth knowledge and experience with human health impacts compared with other civil servants, as indicated by the high weight (74.59\%) assigned to the environmental impacts criteria, which was the highest amongst all three criteria weightings for every other stakeholder group (Figure 3i). They can represent the general inland communities given the minimum interaction with marine affairs. Interviews with representatives indicated their concerns about possible low frequency noise and its impact on human health. However, there is no evidence about the impact of low frequency noise from the onshore wind turbines currently installed in their locality. More justifiable reasons for the selection of the fourth option, i.e., sharing generated electricity as the best option as indicated in Figure 3j, would be the expectation that it will reduce the dependency on conventional non-renewable energy sources (like coal), which would reduce GHG emissions and the expectation of reducing the current economic burden caused by the high electricity demand.

Figure $3 \mathrm{k}, 1$ indicate the criteria weights assigned to and final preference of the respondents from local nonprofit organizations and other community organizations. This group indicated environmental impacts as the most important criterion but selected both the third and fifth options as the preferred options. Since most of these respondents were working closely for the revitalization of the local economy, they expected positive impacts from business involvement opportunities with the new MRE 
sector. According to the discussions with local hotel owners, they expected to revitalize the local tourism industry via future MRE projects. They indicated that there has been a slight improvement in their businesses due to external people visiting the remote islands because of these project developments.

From the results of the stakeholder group-wise option preferences shown in the Figure 3, no solution clearly meets the preferences of all the stakeholder groups. Stakeholder preferences were significantly related to the expected individual costs and benefits as well as the level of knowledge and interaction with the marine activities. Hence, it was important to further analyze the local preferences according to other factors such as geographical area.

\subsection{Geographical Area-Wise Group Decision}

The area-wise analysis results shown in Figure 4 show that there was no significant preference identification for most of the areas (refer to Figure 1 for the geographical locations of the considered areas). Few area-specific factors were identified related to this area-wise preference decisions, which indicates that preference behavior was more dependent on the stakeholders' occupations than area-specific factors. The main reason for not identifying a clear preference decision in Fukue, Nagasaki, and Shimonoseki areas was that respondents represented number of occupations in these groups. Similarly, most respondents from Kitakyushu were from the fishery industry and most respondents from Moji area were from the health and welfare sector. So, a similar preference pattern can be expected from both area-wise preferences and occupation-wise preferences in respective cases. However, key stakeholder interviews provided some information that supports the decision behaviors in the Naru, Kitakyushu, and Moji areas.

The fishery industry, which is the main traditional industry on Naru Island (near the proposed tidal energy project in Nagasaki case study area), is declining rapidly due to the ageing society and inability to attract the younger generation towards the fishing industry. Interviews with the Naru fishery union representatives also mentioned that there are almost no fishing efforts in the Naru strait due to the high tidal current velocity. Hence, they do not expect to interact much with the tidal energy project. Fishers from Naru Island acknowledged that their fishing efforts could benefit from real-time in-situ ocean information provided according to the first option, by estimating the high tidal current conditions that are unique to their area. Naru fishers identified that they could extend their fishing grounds to the high tidal current areas in the Naru strait if they know the exact conditions of the tidal velocity. Such benefits could be provided even with the second option where MRE structures could help fishing in high velocity tidal streams. However, they do not expect much benefit in terms of fishery due to the diminishing nature of the local fishery industry. Despite most of the Naru respondents being fishers, their preferred strategy was the fifth co-existence option, which was using local resources to construct and operate the power plant, creating business involvement opportunities (Figure 4b).

The Kitakyushu respondents' group preferred the first option of sharing oceanographic information (Figure 4h). This may be because the local harbor, which is a powerful stakeholder in the area, values ocean information more than the other non-fishery stakeholders. The respondents from the Moji area (in the Kitakyushu case study area but away from the MRE project area) preferred the fourth option of sharing generated electricity at a subsidized rate (Figure 4j). Their preference decision can be supported by the fact that the electricity supply could being the only direct impact of the MRE projects, which is relatively far from their dwellings. 


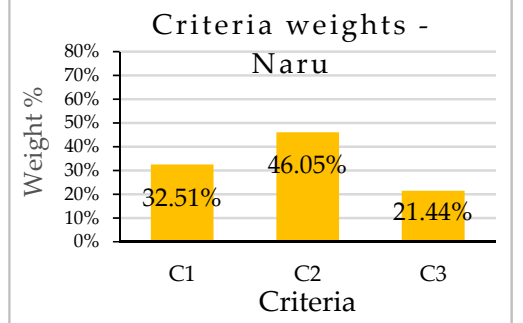

(a)

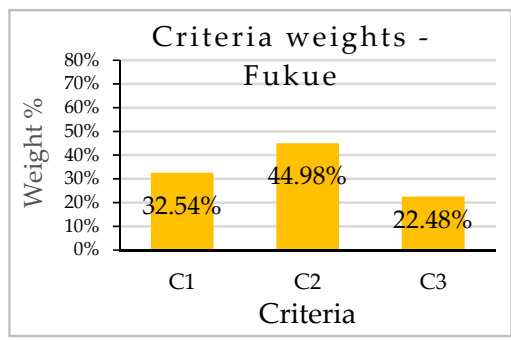

(c)

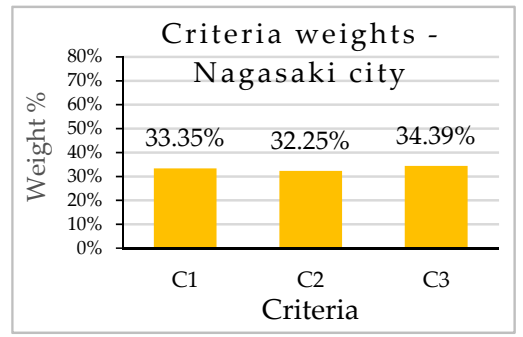

(e)

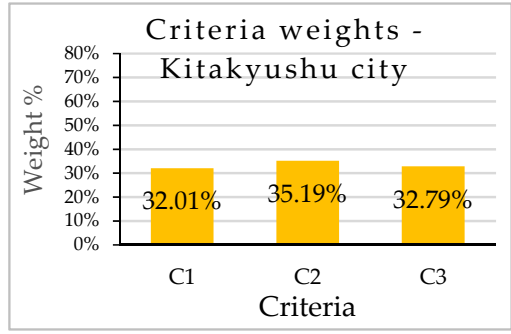

(g)

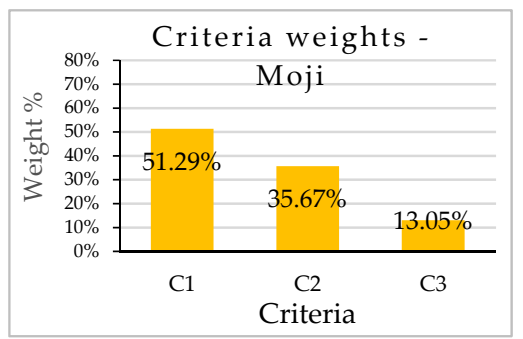

(i)

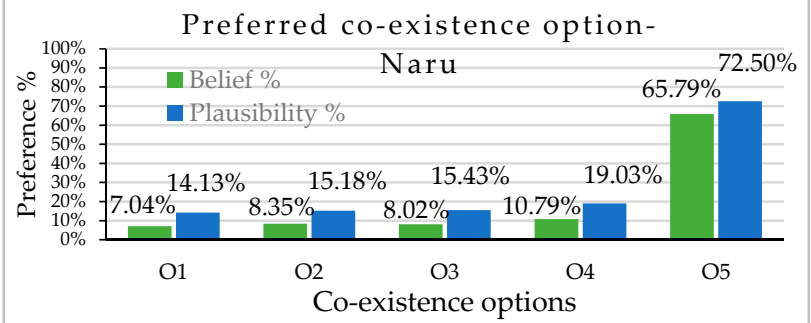

(b)

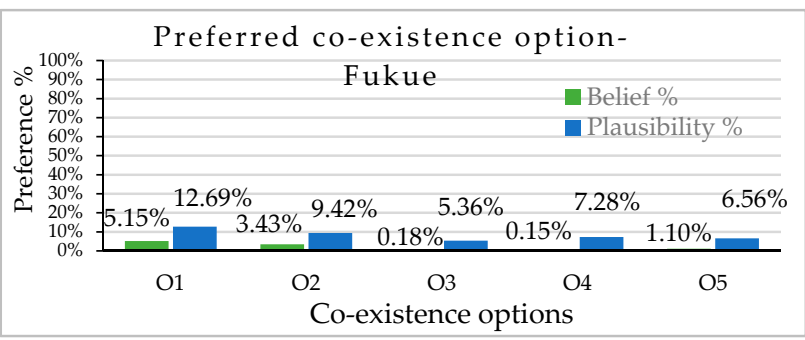

(d)

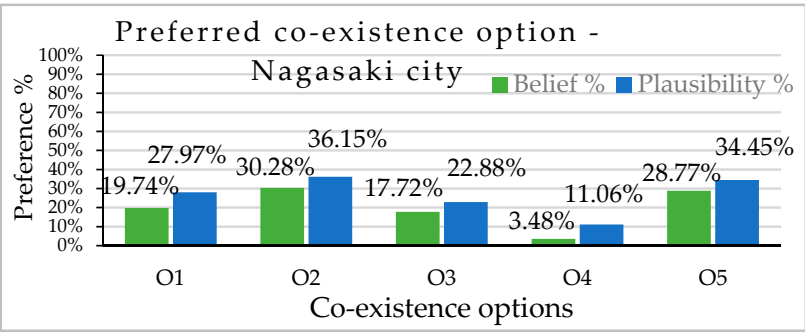

(f)

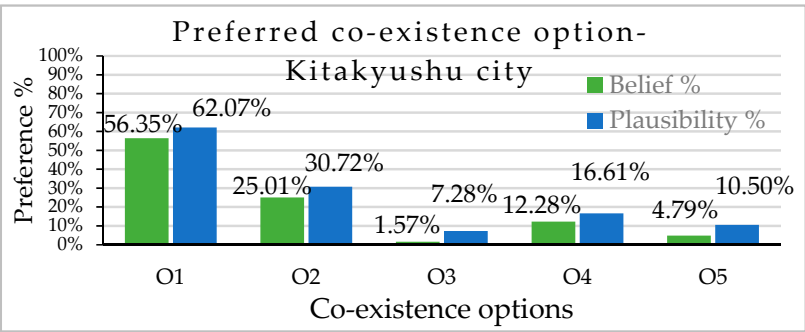

(h)

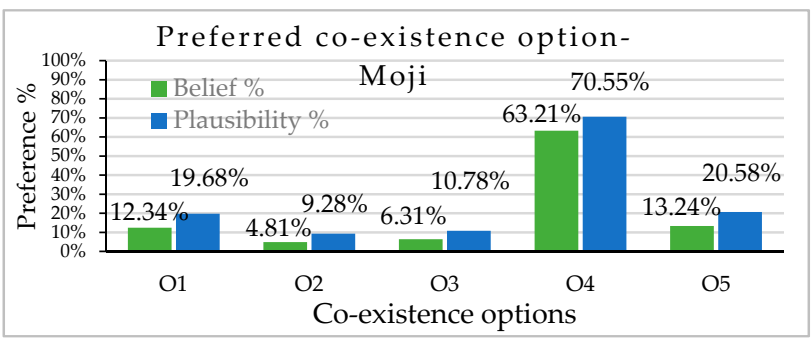

(j)

Figure 4. Cont. 


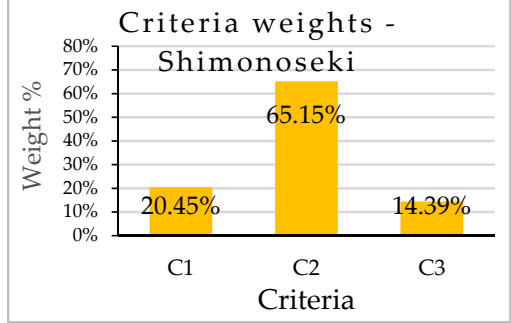

$(\mathbf{k})$

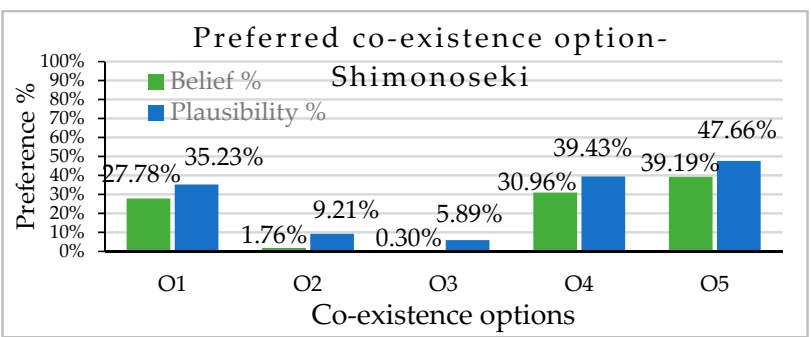

(1)

Figure 4. Case study area-wise preference decision (a) average criteria weights and (b) option preference of respondents from Naru; (c) average criteria weights and (d) option preference of respondents from Fukue; (e) average criteria weights and (f) option preference of respondents from Nagasaki city; (g) average criteria weights and (h) option preference of respondents from Kitakyushu city; (i) average criteria weights and $(\mathbf{j})$ option preference of respondents from Moji; $(\mathbf{k})$ average criteria weights and (l) option preference of respondents from Shimonoseki.

\subsection{Fishers' Preference According to Fishing Methods and Scale}

Fisheries preference was further analyzed due to their unique decision behavior in preferring the first option of sharing oceanographic information. Fisheries are the most prominent stakeholder group in local consensus building process as well as the most impacted local industry from the introduction of MRE projects. Interviews with fishery unions indicated that the impacts of the proposed options highly depend on their fishing methods, fishing grounds and scale. Figure 5 summarizes the fishery preferences based on fishing method and scale. In this analysis, grouping based on fishing method and fishing scale were highly inter-dependent. Most of the small- and medium-scale fishers were using the pole and line fishing method, whereas all respondent fishers who were grouped under the large-scale fishers category were using net fishing and longline fishing as the main fishing methods. Due to this equality of data sets, preference patterns of large-scale fishers and longline and net fishing fishers were exactly the same. Fishers usually use more than one fishing method. The most frequently used fishing method was considered for this grouping. Fishing method was significantly dependent on the fishing area. Most of the local fishers in Fukue and Naru Islands were small-scale fishers mainly using pole and line fishing. Fishers in Kitakyushu area mostly used large-scale fishing methods such as bottom draw nets and set nets.

From the interviews with fishers, we identified that the small-scale fishers who use pole and line method or nearshore fishing methods, such as diving, could benefit from the artificial reef effect and the fish gathering effect created by the subsea MRE structures. Hence, they preferred to have many small-scale MRE devices or structures in the area rather than a few large-scale MRE devices or structures. However, they acknowledged the technical factors that developers have to consider when designing the MRE device layout. In contrast to small-scale fishers, large-scale fishers who use fishing methods which need a large sea area to operate like longline, trawling and net fishing, prefer to have the least amount of MRE devices to minimize their fishing effort displacement. Since they use large sea area, real-time oceanographic information is vital to decide the travel plans and fishing grounds. Finally, large-scale fishers tend to be financially stronger than the small-scale fishers. Hence, large-scale fishers are more focused on the continuity of the industry and less willing to change the current practices, whereas small-scale fishers tended to prioritize different alternatives that provide more financial incentives. Interviews with fishers on Naru Island revealed that they prefer the benefit of having under water structures to support their fishing gears, specifically in the areas with strong tidal currents because, currently, they cannot use their fishing gear most of time due to the high tidal current velocity.

All these factors identified from key stakeholder interviews support the fisheries' preference shown in Figure 5. Large-scale fishers tended to prioritize the second criterion, environmental impacts, whereas small-scale fishers tended to prioritize economic impacts. This behavior can be explained 
by the current financial stability of the particular fishery groups. Generally, all the fishery groups tended to prefer the first option of sharing oceanographic information. However, in contrast with the large-scale fishers who use longline and net fishing methods, small- and medium-scale fishers who mostly use pole and line fishing indicated a significant preference for the second option of using MRE structures as artificial reefs and support structures for fishing gear.

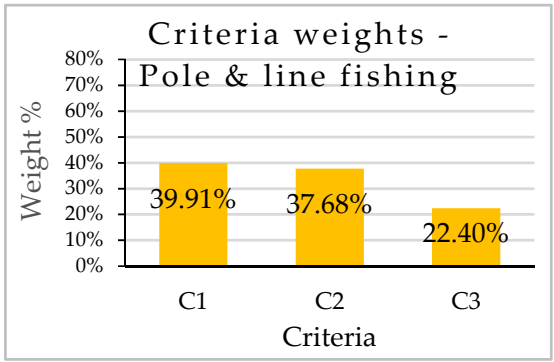

(a)

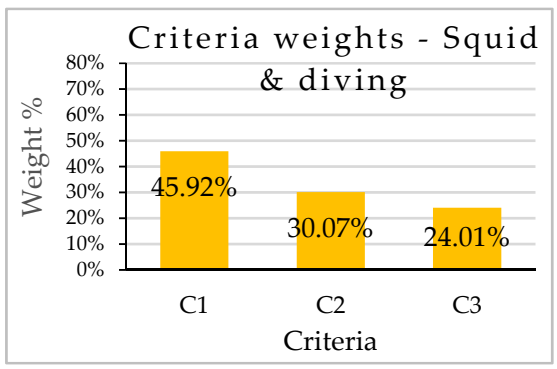

(c)

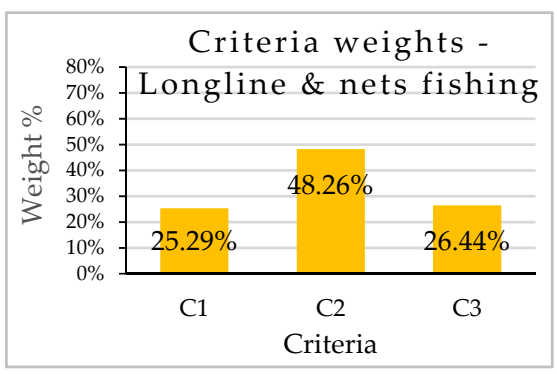

(e)

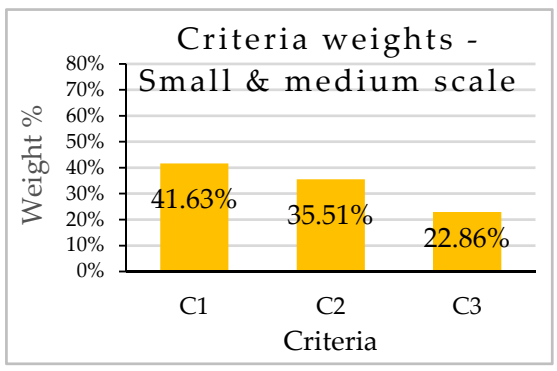

(g)

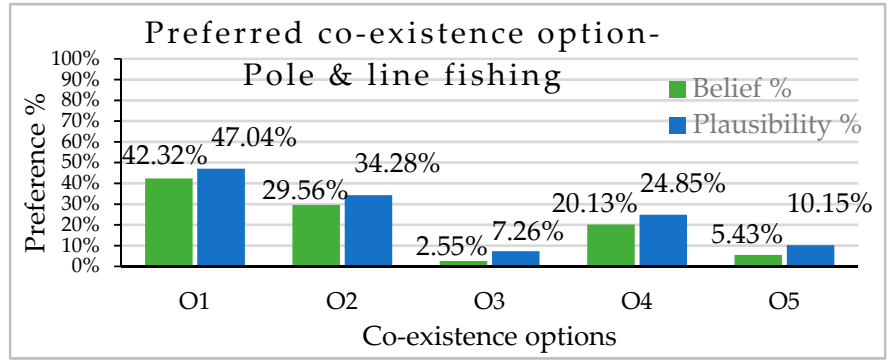

(b)

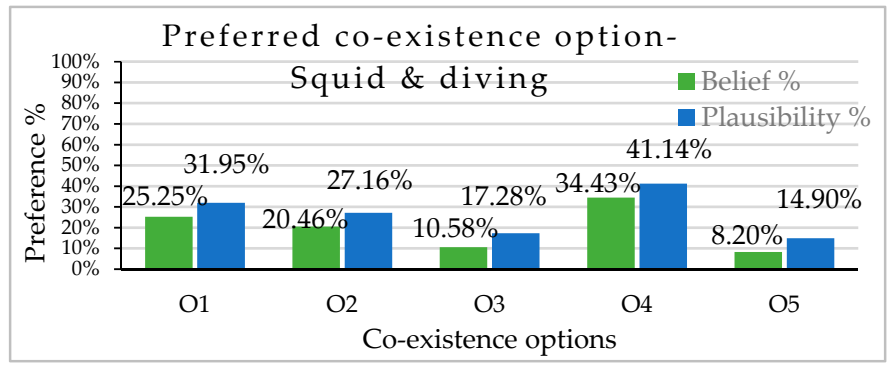

(d)

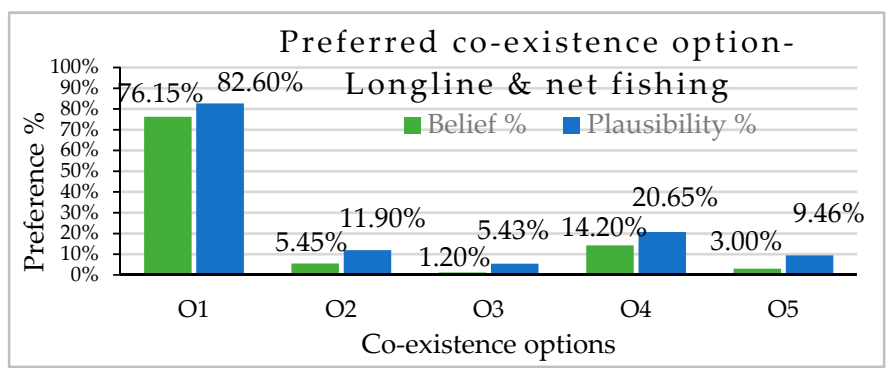

(f)

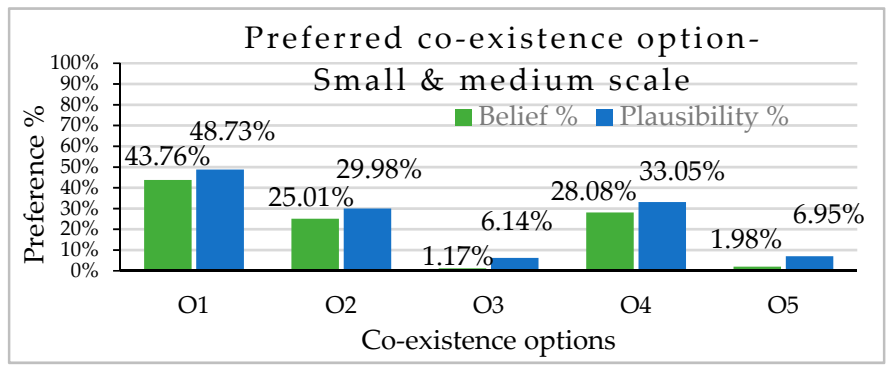

(h)

Figure 5. Cont. 


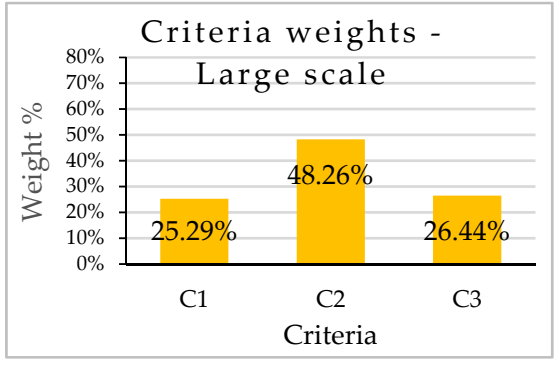

(i)

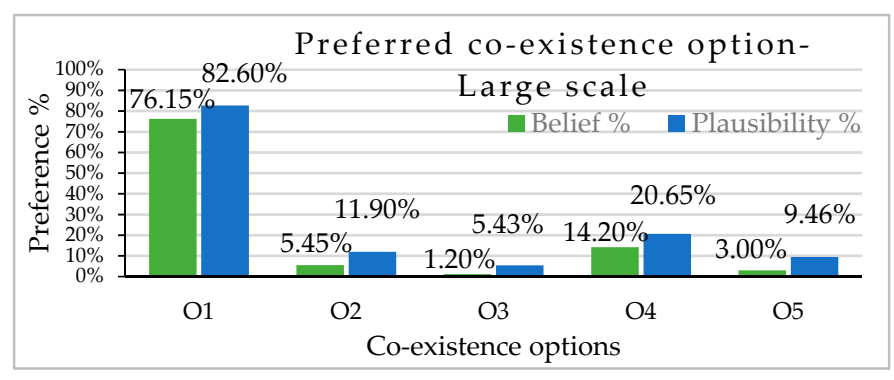

(j)

Figure 5. Fishers' option preference according to fishing method and scale: (a) average criteria weights and (b) option preference of pole and line fishing fishers; (c) average criteria weights and (d) option preference of squid fishing and diving fishers; (e) average criteria weights and (f) option preference of longline and net fishing fishers; (g) average criteria weights and (h) option preference of small and medium scale fishers; (i) average criteria weights and (j) option preference of large scale fishers.

\section{Discussion}

The co-existence of MRE projects with existing marine activities is vital for building consensus among local stakeholders, which is essential for Japan's MRE developers. Understanding the compatibilities and co-location opportunities of different sea uses can lead to an optimum use of available sea area. Consensus building starts with identifying potential feasible negotiation options to create a win-win situation among the stakeholders and then identifying the different stakeholders' preferences for each option. In the case of MRE acceptance, key decision factors are as follows.

\subsection{Nearshore vs. Offshore Projects}

Nearshore MRE projects are more visible to the coastal communities. Hence, interactions between them are common. There is limited ocean space available in the nearshore area for specific marine activities such as shipping and transportation, docking fishery, and other commercial vessels. However, if the visual impacts are considered to be positive and used in a co-existence option, such as in the case of third option in this study, nearshore MRE projects are more preferred than the offshore MRE projects. Going further offshore can enhance the power takeout of the power plant, but increases the construction and operation costs. However, going offshore can create less congestion in the most competitive nearshore areas.

\subsection{Different Technologies within MRE (Offshore Wind vs. Tidal Devices)}

The co-existence strategy is dependent on the MRE technology. Certain types of co-existence options are compatible only with certain types of MRE projects. For example, providing oceanographic information is feasible with most of the MRE projects; however, the quality of data and the available parameters might be different from offshore wind project in comparison to tidal energy projects with fully submerged devices. The second option in this study, using MRE structures as artificial reefs and support structures for fishing gear, is more compatible with offshore wind energy projects than the tidal energy projects. However, tidal energy projects generally create less spatial conflict with fisheries because local fisheries generally do not use strong tidal current areas for fishing activities. Tidal energy projects require different skills and equipment, even for routine maintenance checks. However, some co-existence options can be used independent of the MRE technology used, such as the fourth option in this study-sharing generated electricity.

\subsection{Knowledge, Perceptions and Values vs. Option Preference}

Acceptance and preference depend on the decision makers' knowledge about the context and the perceived impacts of different decision alternatives. Some social science literature highlights the 
impact of personal values and beliefs on acceptance decision [60]. The best examples of this from the results of this study are the health and welfare group decision (Figure 3j) and the group decision of the Moji area residents. (Figure 4j). The health and welfare group perceived noise pollution and prioritized the environmental impacts over economic or social impacts and finally preferred the fourth option of having subsidized electricity. Most of those respondents have experienced nearby onshore wind turbines. The significant concerns about the low frequency noise pollution of offshore wind turbines indicate that they have a different belief about offshore wind turbines in comparison to onshore wind turbines. In contrast, Moji respondents prioritized economic impacts over environmental or social impacts, but still preferred the fourth option, which indicates that preference is highly correlated with personal economic gains.

\subsection{Cost of Co-Existence Options vs. Monetary Compensation Schemes}

The levelized cost of energy (LCOE), which represents the costs of electricity for an MRE installation over an assumed financial life and duty cycle [3], is significantly impacted by the installation costs and operation and maintenance (O\&M) costs [61,62]. Limited information exists about the LCOE of Japan's MRE projects. However, from the literature on the European MRE industry $[56,63,64]$, the initial commercial MRE projects in Japan are estimated to have a significant LCOE. Confidence in the ability of the MRE industry to deliver a competitive LCOE in comparison to other forms of power generation in an acceptable timeframe is essential for continued investment in the sector [65]. Hence, project developers were deeply concerned about managing the project costs to maintain a competitive LCOE with respect to other energy generation options. Even though the main focus of this study was not the analysis of the LCOE of MRE projects, it was important to analyze the potential economic impacts of the proposed co-existence strategies, since those options may significantly impact the LCOE and overall economic sustainability of the projects. The MCA results, in terms of the economic impacts (Table 4), show that stakeholders expect a positive overall impact from the proposed co-existence options except for the fourth option of sharing generated electricity at a subsidized rate. LCOE dynamics for various renewables depend on various factors that could be directly impacted by employing the identified co-existence options. For example, project developers may have to incur additional construction costs if options $\mathrm{O} 1, \mathrm{O} 2$, or $\mathrm{O} 3$ are employed. Conversely, using local resources according to $\mathrm{O} 5$ may reduce O\&M costs. All these co-existence options may indirectly generate positive impacts on LCOE if they lead to a higher local acceptance level. However, there is not enough data to conduct an in-depth analysis of the effect of LCOE from individual co-existence strategies, which is a main limitation of this study.

An alternative to the identified non-monetary co-existence strategies is the monetary compensation or benefit creation scheme where the developers allocate funds to the local community with the mediation of local government, local authority, or some other responsible community body. Developers can benefit from the mediation of a local authority because they tend to have a higher trust among local communities and higher expertise in assessing the local priorities, which is vital when disbursing funds for the needs of the community. However, this kind of monetary benefit creation scheme worsens the developer costs and indirectly affects the LCOE. Developers can benefit if the LCOE impact of the proposed non-monetary co-existence strategies is worse than that of monetary benefit creation schemes. We suggest further studies to evaluate the economic impacts of each option.

\section{Conclusions}

A set of novel co-existence options that can be used to create a win-win situation among local coastal communities and the emerging MRE industry in Japan were evaluated based on DS-AHP in this study. Based on the key stakeholder interview results and a literature survey, the following co-existence options were considered: (1) providing real-time, in-situ ocean information from MRE farms; (2) using MRE structures as artificial reefs and support structures for fishing; (3) co-location with other industries such as leisure, tourism and aquaculture; (4) sharing generated electricity for 
local users at a subsidized rate; and (5) use of local resources to construct and operate the power plant, creating business involvement opportunities. By analyzing the preference results from the questionnaire survey, we found that stakeholders' decisions were mostly based on the perceived impacts on their daily lives. Local residents who interact less with the ocean generally preferred the stakeholder engagement aspect, with the intention of creating local benefits and thereby a win-win situation between the emerging MRE sector and traditional marine industries. Stakeholders who were interacting with the marine areas tended to know the real potential and limitations of the proposed co-existence options. Thus, there was a significant difference between the preference patterns of fishers, developers, and other stakeholders, where the final results indicate that fishers generally preferred the first option of sharing oceanographic information, whereas the general public and project developers preferred the fifth option of using local resources to construct and operate the power plant, thereby creating business involvement opportunities. Since these results were obtained by employing DS-AHP, the impact of uncertainty and data unavailability was minimal. We recommend using this approach not only when new information is available for the decision makers, for example after the initiation of real commercial MRE projects with more certain information and after commissioning the first commercial projects in the area, but also for other instances where stakeholder decisions have to be evaluated amidst a significant level of uncertainty and data unavailability.

Author Contributions: Conceptualization, A.H.T.S.K. and K.T.; methodology, A.H.T.S.K. and S.S.; software, A.H.T.S.K.; validation, A.H.T.S.K., and S.S.; formal analysis, A.H.T.S.K. and S.S.; investigation, K.T. and S.T.; resources, S.T. and K.T.; data curation, S.S.; writing—original draft preparation, A.H.T.S.K.; writing-review and editing, S.S., S.T. and K.T.; visualization, A.H.T.S.K.; supervision, K.T. and S.T.; project administration, A.H.T.S.K. and K.T.; funding acquisition, A.H.T.S.K. and K.T.

Funding: This research work was carried out with the financial support of Graduate Program in Sustainability Science-Global Leadership Initiative in the University of Tokyo. The APC was funded by Takagi Lab, Graduate school of frontier sciences, The University of Tokyo.

Acknowledgments: We are grateful to Hiroshi Matsuo of the Nagasaki Marine Industry Cluster Promotion Association (NaMICPA), Masanobu Shibuya of Shibuya diving industry Co., Ltd./Marine renewable energy-Fisheries co-existence center, and Hiroshi Ohza of the Goto city office for helping us to arrange the key stakeholder interviews. We are thankful to every key informant who participated our interviews. We are also thankful to Hirotaka Matsuda, Rukshani Liyanaarachchi, Norikazu Furukawa, Yuka Shimamura and Yang Jiaqi for the immense support given during the data collection and data analysis stages of this study. We are thankful to Onuki Motoharu, Atsuko Yamada, Yuko Opoku, Izumi Ikeda, and Naomi Sekine for helping with funding arrangements, travel arrangements, and questionnaire survey preparations. We also appreciate the editors and reviewers who gave valuable comments and suggestions to improve the manuscript.

Conflicts of Interest: The authors declare no conflict of interest. The funders had no role in the design of the study; in the collection, analyses, or interpretation of data; in the writing of the manuscript, or in the decision to publish the results.

\section{Abbreviations}

$\begin{array}{ll}\text { AHP } & \text { Analytic Hierarchy Process } \\ \text { BPA } & \text { Basic Probability Assignment } \\ \text { CMS } & \text { Condition Monitoring System (of the MRE power farm) } \\ \text { DST } & \text { Dempster Shafer Theory } \\ \text { DS-AHP } & \text { Dempster Shafer Analytic Hierarchy Process } \\ \text { EMEC } & \text { European Marine Energy Centre } \\ \text { GHG } & \text { Greenhouse Gas } \\ \text { LCOE } & \text { Levelized Cost Of Energy } \\ \text { MCA } & \text { Multi Criteria Analysis } \\ \text { MRE } & \text { Marine Renewable Energy } \\ \text { NaMICPA } & \text { Nagasaki Marine Industry Cluster Promotion Association } \\ \text { NPO } & \text { Non-Profit Organization } \\ \text { O\&M } & \text { Operation and Maintenance } \\ \text { RIOE } & \text { Research Institute of Ocean Economics }\end{array}$




\section{References}

1. Lewis, A.; Estefen, S.; Huckerby, J.; Musial, W.; Pontes, T.; Torres-Martinez, J. Ocean Energy. In IPCC Special Report on Renewable Energy Sources and Climate Change Mitigation; Edenhofer, O., Pichs-Madruga, R., Sokona, Y., Seyboth, K., Matschoss, P., Kadner, S., Zwickel, T., Eickemeier, P., Hansen, G., Schlömer, S., et al., Eds.; Cambridge University Press: Cambridge, UK; New York, NY, USA, 2011; pp. 497-534. Available online: https://www.ipcc.ch/site/assets/uploads/2018/03/Chapter-6-Ocean-Energy-1.pdf (accessed on 21 April 2019).

2. Alistair, G.L. Borthwick, Marine Renewable Energy Seascape. Engineering 2016, 2, 69-78. [CrossRef]

3. Soukissian, T.; Denaxa, D.; Karathanasi, F.; Prospathopoulos, A.; Sarantakos, K.; Iona, A.; Georgantas, K.; Mavrakos, S. Marine Renewable Energy in the Mediterranean Sea: Status and Perspectives. Energies 2017, 10, 1512. [CrossRef]

4. Huckerby, J.; Jeffrey, H.; Sedgwick, J.; Jay, B.; Finlay, L. An International Vision for Ocean Energy-Version II. 2012. Available online: http://www.policyandinnovationedinburgh.org/uploads/3/1/4/1/31417803/oes_ booklet_fa_print_08_10_2012.pdf (accessed on 21 April 2019).

5. Appiott, J.; Dhanju, A.; Cicin-Sain, B. Encouraging renewable energy in the offshore environment. Ocean Coast. Manag. 2014, 90, 58-64. [CrossRef]

6. IEA Wind, Expert Group Summary on Recommended Practices-Social Acceptance of Wind Energy Projects. 2013. Available online: http://www.socialacceptance.ch/images/RP_14_Social_Acceptance_FINAL.pdf (accessed on 21 April 2019).

7. Wiersma, B.; Devine-Wright, P. Public engagement with offshore renewable energy: A critical review, Wiley Interdiscip. Rev. Clim. Chang. 2014, 5, 493-507. [CrossRef]

8. Japan Wind Power Association. JWPA Report on Act on using marine areas for Marine Renewable Energy Projects; Japan Wind Power Association: Tokyo, Japan, 2019; Available online: http://jwpa.jp/page_276_englishsite/ jwpa/detail_e.html (accessed on 21 April 2019).

9. Prime Ministers Headquater for Ocean Policy in Japan, Outline of the Third Basic Plan on Ocean Policy, 2018. Available online: http://www8.cao.go.jp/ocean/english/plan/pdf/plan03_gaiyou_e.pdf (accessed on 21 April 2019).

10. Firestone, J.; Kempton, W. Public opinion about large offshore wind power: Underlying factors. Energy Policy 2007, 35, 1584-1598. [CrossRef]

11. Walker, B.J.A.; Wiersma, B.; Bailey, E. Community benefits, framing and the social acceptance of offshore wind farms: An experimental study in England. Energy Res. Soc. Sci. 2014, 3, 46-54. [CrossRef]

12. Cass, N.; Walker, G.; Devine-Wright, P. Good neighbours, public relations and bribes: The politics and perceptions of community benefit provision in renewable energy development in the UK. J. Environ. Policy Plan. 2010, 12, 255-275. [CrossRef]

13. Aitken, M. Wind power and community benefits: Challenges and opportunities. Energy Policy 2010, 38, 6066-6075. [CrossRef]

14. Walker, B.J.A.; Russel, D.; Kurz, T. Community Benefits or Community Bribes? An Experimental Analysis of Strategies for Managing Community Perceptions of Bribery Surrounding the Siting of Renewable Energy Projects. Environ. Behav. 2017, 49, 59-83. [CrossRef]

15. Reilly, K.; O'Hagan, A.M.; Dalton, G. Developing benefit schemes and financial compensation measures for fishermen impacted by marine renewable energy projects. Energy Policy 2016, 97, 161-170. [CrossRef]

16. Yates, K.L.; Schoeman, D.S. Spatial Access Priority Mapping (SAPM) with Fishers: A Quantitative GIS Method for Participatory Planning. PLoS ONE 2013, 8. [CrossRef]

17. RIOE (Research Institute for Ocean Economics-Japan). Recommendations on Consensus Building with Fishery Cooperatives for Offshore Wind Power Projects; RIOE: Chiba, Japan, 2013; Available online: http: //www.rioe.or.jp/0510teigen.pdf (accessed on 21 April 2019).

18. Goto City Office, Goto Ocean Energy, (n.d.) 1-15. Available online: https://www.env.go.jp/nature/biodic/ coralreefs/icccrc2013/pdf/year2013630/section2/noguchi.pdf (accessed on 21 April 2019).

19. Nagasaki Marine Industry Cluster Promotion Association (NaMICPA), (n.d.). Available online: http: //namicpa.jp/ (accessed on 7 August 2018).

20. Japan Wind Power Association. Offshore Wind Power Development in Japan; Japan Wind Power Association: Tokyo, Japan, 2017; 28p, Available online: http://jwpa.jp/pdf/20170228_OffshoreWindPower_inJapan_r1.pdf (accessed on 21 April 2019). 
21. Waldman, S.; Yamaguchi, S.; Murray, R.O.; Woolf, D. Tidal resource and interactions between multiple channels in the Goto Islands, Japan. Int. J. Mar. Energy 2017, 19, 332-334. [CrossRef]

22. New Energy and Industrial Technology Development Organisation (NEDO). NEDO Offshore Wind Energy Progress, 2nd ed.; NEDO: Kawasaki City, Japan, 2013; 24p, Available online: http://www.nedo.go.jp/content/ 100534312.pdf?from =b (accessed on 21 April 2019).

23. Hibiki Wind Energy Co. Ltd. Hibiki Wind Energy; Hibiki Wind Energy Co. Ltd.: Kyushu, Japan, 2018; 4p, Available online: http://hibikiwindenergy.co.jp/pdf/hwe_english.pdf (accessed on 21 April 2019).

24. Saaty, R.W. The analytic hierarchy process-What it is and how it is used. Math. Model. 1987, 9, 161-176. [CrossRef]

25. Saaty, T.L. How to make a decision: The analytic hierarchy process. Eur. J. Oper. Res. 1990, 48, 9-26. [CrossRef]

26. Dempster, A. Upper and lower probabilities induced by a multi-valued mapping. Ann. Math. Stat. 1967, 38, 325-339. [CrossRef]

27. Dempster, A. A Generalization of Bayesian Inference. J. R. Stat. Soc. Ser. B 1968, 30, 205-232. [CrossRef]

28. Shafer, G. A Mathematical Theory of Evidence; Princeton University Press: Princeton, NJ, USA, 1976.

29. Beynon, M.J.; Cosker, D.; Marshall, D. An expert system for multi-criteria decision making using Dempster Shafer theory. Expert Syst. Appl. 2001, 20, 357-367. [CrossRef]

30. Beynon, M.J. DS/AHP method: A mathematical analysis, including an understanding of uncertainty. Eur. J. Oper. Res. 2002, 140, 148-164. [CrossRef]

31. Beynon, M.J. A method of aggregation in DS/AHP for group decision-making with the non-equivalent importance of individuals in the group. Comput. Oper. Res. 2005, 32, 1881-1896. [CrossRef]

32. Awasthi, A.; Chauhan, S.S. Using AHP and Dempster-Shafer theory for evaluating sustainable transport solutions. Environ. Model. Softw. 2011, 26, 787-796. [CrossRef]

33. Kinoshita, K. Evaluation of Regional Characteristics of Wave Energy and Research of Mooring System. 2010. Available online: https://www.env.go.jp/earth/ondanka/cpttv_funds/pdf/prod20100301.pdf (accessed on 21 April 2019).

34. Fischer, J.; Flemming, N. Operational Oceanography: Data Requirements Survey; EuroGOOS Publication No. 12; Southampton Oceanography Centre: Southampton, UK, 1999; ISBN 0-904175-36-7. Available online: https://www.academia.edu/21168082/The_EuroGOOS_data_requirements_survey (accessed on 11 May 2019).

35. Chiabai, A.; Nunes, P.A.L.D. Economic Valuation of Oceanographic Forecasting Services: A Cost-Benefit Exercise, 2006. Available online: http://www.feem.it/userfiles/attach/Publication/NDL2006/NDL2006-104.pdf (accessed on 21 April 2019).

36. Francisco, F.; Sundberg, J. Detection of Visual Signatures of Marine Mammals and Fish within Marine Renewable Energy Farms using Multibeam Imaging Sonar. J. Mar. Sci. Eng. 2019, 7, 22. [CrossRef]

37. Hooper, T.; Austen, M. The co-location of offshore windfarms and decapod fisheries in the UK: Constraints and opportunities. Mar. Policy 2014, 43, 295-300. [CrossRef]

38. Hooper, T.; Ashley, M.; Austen, M. Perceptions of fishers and developers on the co-location of offshore wind farms and decapod fisheries in the UK. Mar. Policy 2015, 61, 16-22. [CrossRef]

39. de Groot, J.; Campbell, M.; Ashley, M.; Rodwell, L. Investigating the co-existence of fisheries and offshore renewable energy in the UK: Identification of a mitigation agenda for fishing effort displacement. Ocean Coast. Manag. 2014, 102, 7-18. [CrossRef]

40. Stelzenmüller, V.; Diekmann, R.; Bastardie, F.; Schulze, T.; Berkenhagen, J. Co-location of passive gear fisheries in offshore wind farms in the German EEZ of the North Sea: A first socio-economic scoping. J. Environ. Manag. 2016, 183, 794-805. [CrossRef]

41. Blyth-Skyrme, R. Benefits and Disadvantages of Co-Locating Windfarms and Marine Conservation Zones; Report to Collaborative Offshore Wind Research into the Environment Ltd.: London, UK, 2010; p. 37. Available online: https://tethys.pnnl.gov/sites/default/files/publications/Blyth-Skyrme-2011.pdf (accessed on 21 April 2019).

42. Gimpel, A.; Stelzenmuller, V.; Grote, B.; Buck, B.H.; Floeter, J.; Nunez-Riboni, I.; Pogoda, B.; Temming, A. A GIS modelling framework to evaluate marine spatial planning scenarios: Co-location of offshore wind farms and aquaculture in the German EEZ. Mar. Policy 2015, 55, 102-115. [CrossRef] 
43. Mackinson, S.; Curtis, H.; Brown, R.; Mctaggart, K.; Taylor, N.; Neville, S.; Rogers, S. A report on the perceptions of the fishing industry into the potential socio-economic impacts of offshore wind energy developments on their work patterns and income. Sci. Ser. Tech. Rep. Cefas Lowestoft 2006, 133, 99. Available online: https://tethys.pnnl.gov/sites/default/files/publications/Perceptions_of_the_Fishing_Industry_on_ Offshore_Wind.pdf (accessed on 21 April 2019).

44. Buck, B.H.; Krause, G.; Rosenthal, H. Extensive open ocean aquaculture development within wind farms in Germany: The prospect of offshore co-management and legal constraints. Ocean Coast. Manag. 2004, 47, 95-122. [CrossRef]

45. Buck, B.H.; Langan, R. Aquaculture Perspective of Multi-Use Sites in the Open Ocean; Springer: Berlin, Germany, 2017. [CrossRef]

46. Wang, L. Comparative Study of Wind Turbine Placement Methods for Flat Wind Farm Layout Optimization with Irregular Boundary. Appl. Sci. 2019, 9, 639. [CrossRef]

47. Fayram, A.H.; de Risi, A. The potential compatibility of offshore wind power and fisheries: An example using bluefin tuna in the Adriatic Sea. Ocean Coast. Manag. 2007, 50, 597-605. [CrossRef]

48. Westerberg, V.; Jacobsen, J.B.; Lifran, R. The case for offshore wind farms, artificial reefs and sustainable tourism in the French mediterranean. Tour. Manag. 2013, 34, 172-183. [CrossRef]

49. RYA \& CA. 'Sharing the Wind' Recreational Boating in the Offshore Wind Farm Strategic Areas, 2004. Available online: https://www.rya.org.uk/sitecollectiondocuments/legal/WebDocuments/Environment/ SharingtheWindcompressed.pdf (accessed on 21 April 2019).

50. MAFF (Ministry of Agriculture Forestry and Fisheries). Japan, Promotion Project of Eco-Friendly Fishing Ports; MAFF: Tokyo, Japan, 2012. Available online: http://www.maff.go.jp/j/aid/hozyo/2012/suisan/pdf/80.pdf (accessed on 21 April 2019).

51. Cascajo, R.; García, E.; Quiles, E.; Correcher, A.; Morant, F. Integration of Marine Wave Energy Converters into Seaports: A Case Study in the Port of Valencia. Energies 2019, 12, 787. [CrossRef]

52. Clayton, M.; Stillwell, A.; Webber, M. Implementation of Brackish Groundwater Desalination Using Wind-Generated Electricity: A Case Study of the Energy-Water Nexus in Texas. Sustainability 2014, 6, 758-778. [CrossRef]

53. FLOWW Fishing Liaison with Offshore Wind and Wet Renewables Group. Recommendations for Fisheries Liaison, 2008. Available online: https:/webarchive.nationalarchives.gov.uk/+/http:/www.berr.gov.uk/files/ file46366.pdf (accessed on 21 April 2019).

54. Seyr, H.; Muskulus, M. Decision Support Models for Operations and Maintenance for Offshore Wind Farms: A Review. Appl. Sci. 2019, 9, 278. [CrossRef]

55. Nachimuthu, S.; Zuo, M.J.; Ding, Y. A Decision-making Model for Corrective Maintenance of Offshore Wind Turbines Considering Uncertainties. Energies 2019, 12, 1408. [CrossRef]

56. OES-IEA. International Levelised Cost of Energy for Ocean Energy Technologies, 2015. p. 35. Available online: http://www.ocean-energy-systems.org/news/international-lcoe-for-ocean-energy-technology/?source= newsletter (accessed on 21 April 2019).

57. Gao, X.; Xia, L.; Lu, L.; Li, Y. Analysis of Hong Kong's Wind Energy: Power Potential, Development Constraints, and Experiences from Other Countries for Local Wind Energy Promotion Strategies. Sustainability 2019, 11, 924. [CrossRef]

58. Ishidoya, H. Studies on Kyucho Events and Disaster Prevention of Set Nets in Sagami Bay. Fish. Sci. 2002, 68, 1841-1844. [CrossRef]

59. Matsuyama, M.; Ishidoya, H.; Iwata, S.; Kitade, Y.; Nagamatsu, H. Kyucho induced by intrusion of Kuroshio water in Sagami Bay, Japan. Cont. Shelf Res. 1999, 19, 1561-1575. [CrossRef]

60. Bidwell, D. Ocean beliefs and support for an offshore wind energy project. Ocean Coast. Manag. 2017, 146, 99-108. [CrossRef]

61. Myhr, A.; Bjerkseter, C.; Ågotnes, A.; Nygaard, T.A. Levelised cost of energy for offshore floating wind turbines in a lifecycle perspective. Renew. Energy 2014, 66, 714-728. [CrossRef]

62. Allan, G.; Gilmartin, M.; McGregor, P.; Swales, K. Levelised Costs of Wave and Tidal Energy in the UK: Cost Competitiveness and the Importance of "Banded" Renewables Obligation Certificates. Energy Policy 2011, 39, 23-39. [CrossRef] 
63. Astariz, S.; Vazquez, A.; Iglesias, G. Evaluation and comparison of the levelized cost of tidal, wave, and offshore wind energy. J. Renew. Sustain. Energy 2015, 7, 053112. [CrossRef]

64. Lerch, M.; De-Prada-Gil, M.; Molins, C.; Benveniste, G. Sensitivity analysis on the levelized cost of energy for floating offshore wind farms. Sustain. Energy Technol. Assess. 2018, 30, 77-90. [CrossRef]

65. Weller, S.; Thies, P.; Gordelier, T.; Johanning, L. Reducing Reliability Uncertainties for Marine Renewable Energy. J. Mar. Sci. Eng. 2015, 3, 1349-1361. [CrossRef]

(c) (

(C) 2019 by the authors. Licensee MDPI, Basel, Switzerland. This article is an open access article distributed under the terms and conditions of the Creative Commons Attribution (CC BY) license (http://creativecommons.org/licenses/by/4.0/). 